\title{
Immunological and physiopathological approach of COVID-19 in pregnancy
}

\author{
Raquel Ferrer-Oliveras ${ }^{1}\left({ }^{10} \cdot\right.$ Manel Mendoza $^{2} \odot \cdot$ Sira Capote $^{1} \cdot$ Laia Pratcorona $^{3} \cdot$ Enrique Esteve-Valverde $^{4,5}$. \\ Lluis Cabero-Roura ${ }^{1,6} \cdot$ Jaume Alijotas-Reig ${ }^{7,8,9}$
}

Received: 20 November 2020 / Accepted: 31 March 2021 / Published online: 4 May 2021

(C) The Author(s), under exclusive licence to Springer-Verlag GmbH Germany, part of Springer Nature 2021

\begin{abstract}
Coronavirus disease-2019 (COVID-19) related to Coronavirus-2 (SARS-CoV-2) is a worldwide health concern. Despite the majority of patients will evolve asymptomatic or mild-moderate upper respiratory tract infections, $20 \%$ will develop severe disease. Based on current pathogenetic knowledge, a severe COVID-19 form is mainly a hyperinflammatory, immunemediated disorder, triggered by a viral infection. Due to their particular immunological features, pregnant women are supposed to be particularly susceptible to complicate by intracellular infections as well as immunological disturbances. As an example, immune-thrombosis has been identified as a common immune-mediated and pathogenic phenomenon both in COVID-19, in obstetric diseases and in COVID-19 pregnant women. According to extensive published clinical data, is rationale to expect an interference with the normal development of pregnancy in selected SARS-CoV-2-infected cases, mainly during third trimester.

This manuscript provides insights of research to elucidate the potential harmful responses to SARS-CoV-2 and /or other coronavirus infections, as well as bidirectional interactions between COVID-19 and pregnancy to improve their respective management.
\end{abstract}

Keywords COVID-19 $\cdot$ Immune-mediated $\cdot$ SARS-CoV-2 $\cdot$ Pregnancy outcome $\cdot$ Placental disease $\cdot$ Hyperinflammation $\cdot$ Obstetric disorder · Viral infection

$\begin{array}{llll}\text { Abbreviations } & & \text { BNP } & \text { B-type natriuretic peptide } \\ \text { ACE-2 } & \text { Angiotensin-converting enzyme-2 } & \text { MAC } & \text { Membrane attack complex (C5-9) } \\ \text { ADE } & \text { Antibody dependent enhancement } & \text { COVID-19 } & \text { Coronavirus disease 2019 } \\ \text { ADRS } & \text { Acute distress respiratory syndrome } & \text { DAF } & \text { Decay-accelerating factor } \\ \text { Ang } & \text { Angiotensin } & \text { HLA } & \text { Human leucocyte antigen } \\ \text { APC } & \text { Antigen-presenting cells } & \text { HELLP } & \text { Hemolysis, elevated liver enzymes, low- } \\ \text { aPL } & \text { Antiphospholipid antibodies } & & \text { platelet count }\end{array}$

Raquel Ferrer-Oliveras

raquelfo22@hotmail.com

$\triangle$ Jaume Alijotas-Reig

jalijotas@ vhebron.net

1 Department of Obstetrics and Gynaecology, Hospital Universitari Quironsalud Barcelona, Barcelona, Catalonia, Spain

2 Maternal Fetal Medicine Unit, Department of Obstetrics, Hospital Universitari Vall d'Hebron, Universitat Autònoma de Barcelona, Barcelona, Catalonia, Spain

3 Department of Obstetrics, Hospital Germans Trias i Pujol, Universitat Autònoma de Barcelona, Barcelona, Catalonia, Spain
4 Department of Internal Medicine, Althaia Network Health. Manresa, Barcelona, Spain

5 Universitat Central de Catalunya, Barcelona, Catalonia, Spain

6 Prof. Emeritus of Obsterics and Gynaecology, Universitat Autònoma de Barcelona, Barcelona, Catalonia, Spain

7 Systemic Autoimmune Diseases Unit. Department of Internal Medicine-1, Vall d' Hebron University Hospital, Barcelona, Spain

8 Systemic Autoimmune Research Unit, Vall d'Hebron Reseacrh Institute, Barcelona, Spain

9 Department of Medicine, Universitat Autònoma de Barcelona, Barcelona, Spain 


$\begin{array}{ll}\text { HPS } & \text { Haemophagocytic syndrome } \\ \text { IFN } \gamma & \text { Interferon gamma } \\ \text { IL } & \text { Interleukin } \\ \text { MHC-II } & \text { Major histocompatibility type-II } \\ \text { MAS } & \text { Macrophage activation syndrome } \\ \text { MBL } & \text { Mannose binding lectin } \\ \text { MERS-CoV } & \text { Middle East Respiratory Syndrome } \\ & \text { Coronavirus } \\ { }_{\text {NF- }} \beta & \text { Nuclear Factor- } \beta \\ \text { NT-proBNP } & \text { N-terminal fragment of B-type natriuretic } \\ & \text { peptide } \\ \text { NK } & \text { Natural killer cells } \\ \text { uNK } & \text { Uterine natural killer cells } \\ \text { PE } & \text { Preeclampsia } \\ \text { PLGF } & \text { Placental growth factor } \\ \text { PRR } & \text { Pattern recognition receptors } \\ \text { RA } & \text { Rheumatoid arthritis } \\ \text { RAS } & \text { Renin-angiotensin aldosterone system } \\ \text { SARS-CoV-2 } & \text { Severe Acute Respiratory Syndrome } \\ & \text { Coronavirus-2 } \\ \text { sENG } & \text { Soluble endoglin } \\ \text { sFlt-1 } & \text { Soluble fms-like tyrosine kinase -1 } \\ \text { SLE } & \text { Systemic Lupus Erythematosus } \\ \text { TLR } & \text { Toll-Like Receptor } \\ \text { TNF- } \alpha & \text { Tumour necrosis factor-alpha } \\ \text { TRAASVIR } & \text { Thrombotic Risk Associated with } \\ & \text { Antiphospholipid Syndrome after Viral } \\ \text { TGF- } \beta & \text { infection } \\ \text { Tregs } & \text { Transforming growth factor-beta } \\ \text { VEGF } & \text { Regulatory T-cells } \\ & \text { Vascular endothelial growth factor } \\ & \end{array}$

\section{Introduction}

The coronavirus disease 2019 (COVID-19) caused by the Severe Acute Respiratory Syndrome coronavirus 2 (SARSCoV-2), was first described as an epidemic in China (Wuhan, Hubei province) in December 2019 [1]. Only 3 months later, the World Health Organization (WHO) declared the outbreak a global pandemic [2] and a public health emergency of international concern due to its highly contagious nature, and its morbidity and mortality rates, which could rise up to $3-4 \%[2,3]$.

SARS-CoV-2 is the seventh and the larger type of enveloped simple strained RNA coronavirus species that has been demonstrated to be able to infect humans [4]. The Severe Acute Respiratory Syndrome coronavirus 1 (SARS-CoV-1) and the Middle East respiratory syndrome coronavirus (MERS-CoV) are two zoonotic coronaviruses that were responsible for epidemic outbreaks with a great local impact in 2002 in China, and in 2012 in Saudi Arabia, respectively [5]. Their global impact, however, was relatively low. COVID-19, by contrast, has spread rapidly worldwide, becoming a global health threat. A low rate of previously exposed individuals in different communities, and the antigenic diversity among coronaviruses, could explain the explosive COVID-19 outbreak [6]. Researchers have struggled to understand the diversity in the molecular pathways of the human hosts' immune system responses to SARS-CoV-2 [5-7].

SARS-CoV-2 infection has a triggering role of the immune system. For this reason, pregnant women are ofspecial interest, due to their unique immunological temporary features. This manuscript summarizes existing literature of the molecular mechanisms that may be underlying in the obstetric manifestations of pregnant women infected with SARS-CoV-1, MERS-CoV or SARS-CoV-2.

\section{COVID-19: an immunological disorder underlying a clinical disease}

Like in SARS-CoV-1 and MERS-CoV, COVID-19 features a range in symptoms from: asymptomatic or mild upper respiratory tract infections (80\%); through flu-like syndromes to systemic inflammatory responses, undergoing more complicated forms of the disease, like severe bilateral pneumonia (15\%); to Severe Acute Respiratory Syndrome (SARS) and/ or multisystemic involvement (5\%) requiring admission to intensive care units (ICU) for continuous and invasive support $[8,9]$. Adults, specifically older men with comorbidities such as obesity, high blood pressure, cardiovascular or chronic lung diseases, are more likely to suffer severe lifethreatening forms of COVID-19, that eventually lead them to death $[8,9]$.

A five-stage model has been proposed to explain the clinical spectrum of COVID-19 disease. These stages correlate with a direct viral effect to triggered responses of both the innate and adaptive immune systems $[1,9,10]$. The different stages are represented in Fig. 1.

\section{Incubation and early infection. Stage 0 and Stage 1}

SARS-CoV-2 infection is transmitted person-to-person, airborne or via direct contact, nasal and oropharyngeal mucosa being the main entrance path of the virus into the human host. The mechanism of SARS-CoV-2 that makes host cell entry possible, is the Spike protein (S protein) on the envelope that binds to a cell membrane receptor, angiotensin converting enzyme (ACE) homolog 2 (ACE2), which is a part of the renin-angiotensin-aldosterone system (RAS). The $\mathrm{S}$ protein is cleaved into $\mathrm{S} 1$ and $\mathrm{S} 2$ by a human cell-derived protease (proteolytic enzyme). S1 


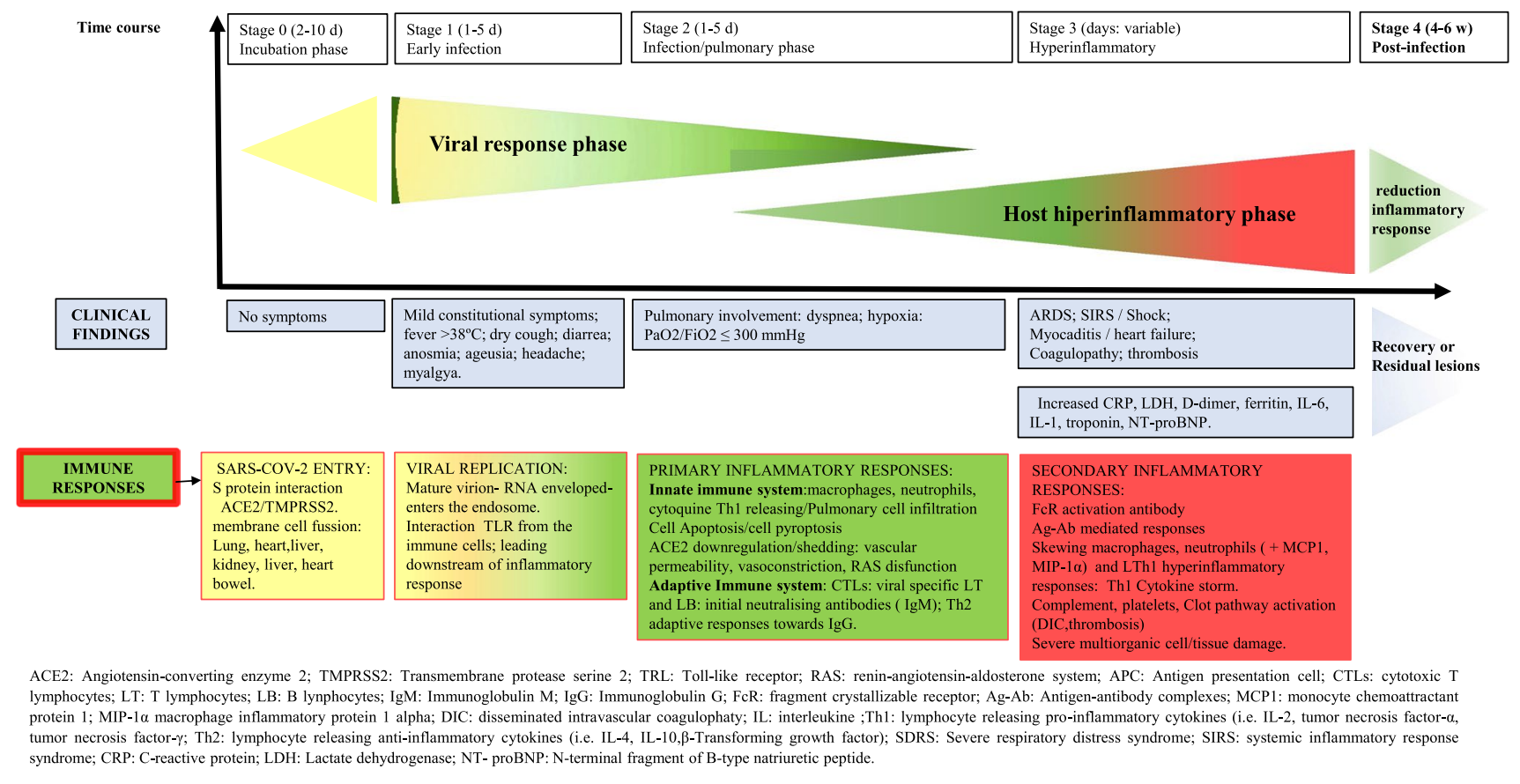

Fig. 1 Five stage model to explain clinical and immunological spectrum of COVID-19 disease

binds to its receptor, ACE2. The other fragment, S2, is cleaved by transmembrane protease, serine 2 (TMPRSS2), a human cell surface serine protease, resulting in membrane fusion [11, 12]. SARS-CoV-2, thusly, infects ACE2 cells, which include mainly oral mucosa, lungs, alveoli, kidney, liver, intestinal and all endothelial cells $[12,13]$. After entering the cells, the viral RNA genome is released into the cytoplasm and is translated into polyproteins and structural proteins, and then, the viral genome begins to replicate [14]. The mature virion enters the endosome and interacts with toll-like receptors (TLR) from the immune cells to stimulate downstream inflammatory and clot pathways. Despite sharing almost $70 \%$ of the amino acid sequences of SARS-CoV-1, and having the same functional receptor (ACE2), SARS-CoV-2 is more contagious than SARS-CoV-1 and MERS-CoV [5, 15]. It has two main genomic polymorphisms; the newest and the most predominant one, L type ( $70 \%)$ is meant to be more aggressive, and spreads quicker than others $[14,16,17]$. One possible explanation is that in SARS-CoV-2 infection, the IFN-I type response, -a protective pathway through infected cells usually modulate innate immune responses, promoting balanced antigen presentation and natural killer cell functions, while reducing proinflammatory cytokine production- [18], is suppressed, and therefore viruses rapidly replicate $[7,19]$.

\section{Primary inflammatory responses. Infection/ pulmonary phase. Stage 2}

These primary inflammatory responses are mainly driven by active viral replication. The cellular effectors of the innate immune system are mainly macrophages and neutrophils that massively respond by producing reactive oxygen species (ROS), viral antigenic peptides, and specific tissue matrix metalloprotease (MMP). The core activity of innate immune system in this stage, is the release of proinflammatory cytokines like pro-IL-1 $\beta$ [20] that is cleaved by caspase- 1 and converted into active mature IL- $1 \beta$. This is the very first mediator of lung inflammation and the ensuing epithelial and endothelial cell apoptosis, vascular leakage and tissue damage $[8,20]$. After the innate system, the adaptive immune system rapidly comes onto the scene through antigen-dependent lymphocyte activation by antigen presenting cells (APC) bearing viral antigenic peptides on human leukocyte antigens (HLA) molecules. Some gene polymorphisms, i.e., mannose-binding lectin (MBL) expressed in the virus that determine pattern recognition receptors (PRR), could define the different responses in the host [21]. The APC-viral antigen complexes are recognized by virus-specific cytotoxic $\mathrm{T}$ lymphocytes (CTLs), which are mediated by virus-specific B and T cells $(\mathrm{CD} 8+, \mathrm{CD} 4+)$, secreting at different times typical of viral-induced patterns of neutralizing antibodies (IgM and $\operatorname{IgG}$ ) [7, 21]. Besides these inflammatory responses, a persistent waste of active macrophages, neutrophils and lymphocytes still remain, 


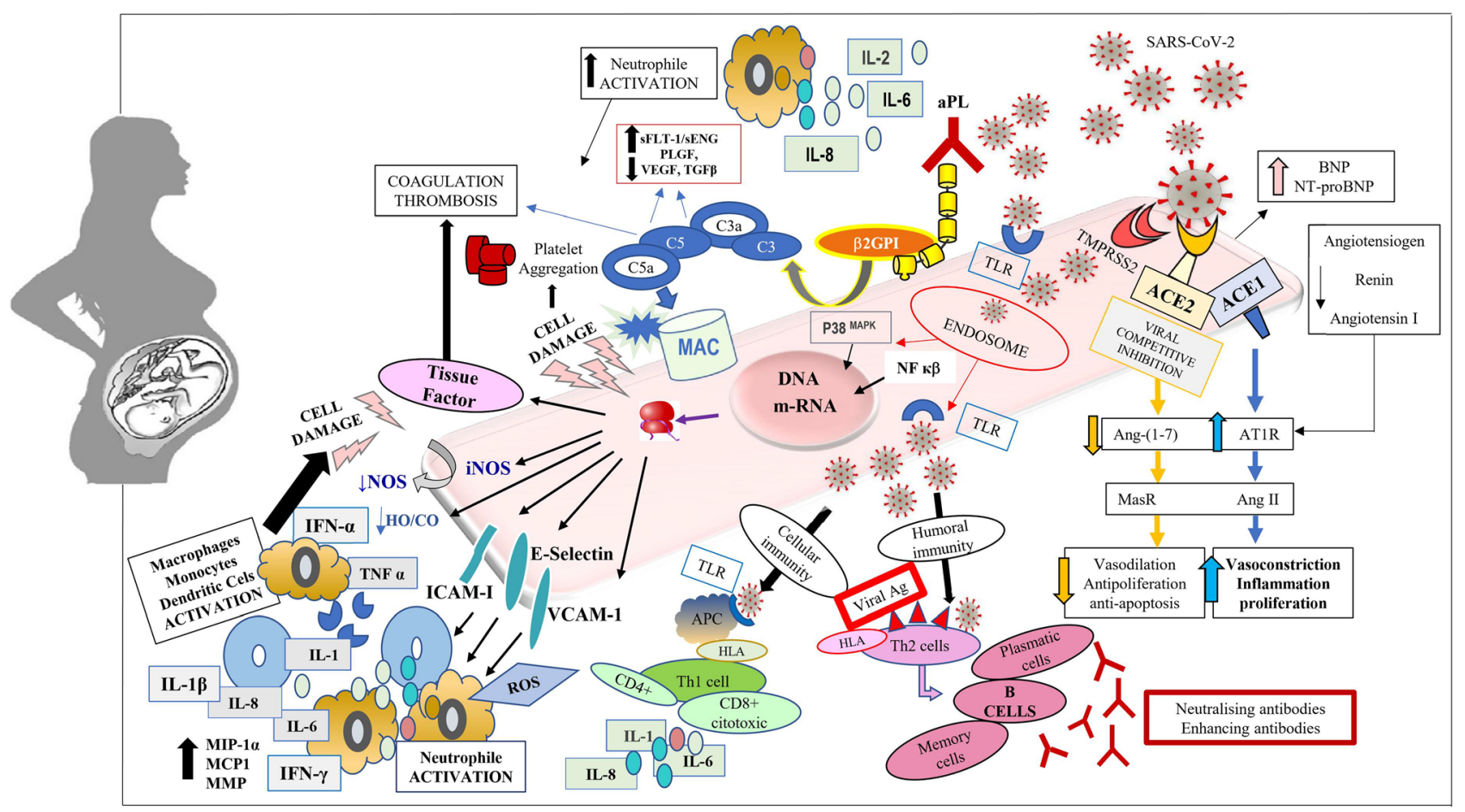

Fig. 2 SARS-CoV 2 infection in pregnancy: hypothetical pathogenic pathways in endothelial cells. The figure represents all molecular pathogenic pathways tha may happen when SARS-CoV-2 infects endothelial cells in context of pregnancy, including the fetal-maternal interface endothelial cells. The mechanism of SARS-CoV-2 human cell entry is possible as the Spike protein (S protein) on the envelope binds to the cell membrane glycoprotein angiotensin converting enzyme (ACE) homolog 2 (ACE2), which is involved in the reninangiotensin-aldosterone system (RAS). The $\mathrm{S}$ protein is cleaved into $\mathrm{S} 1$ and $\mathrm{S} 2$, which enhance ACE2 and TMPRSS2, respectively. The binding induces competitive inhibition, causing ACE2 downregulation and shedding, reducing Ang- 1-7 synthesis while shifting to an increase of ACE1 activity, increasing Ang II and turning to vasoconstriction, inflammation and vascular permeability. After entering the cells, the viral RNA genome is released into the cytoplasm and is translated into polyproteins and structural proteins, after which the viral genome begins to replicate.The mature virion enters the endosome and interacts with toll-like receptors (TLR) from the immune cells to stimulate downstream inflammatory and clot pathways. The viral nuclear integration could induce protein expression in the infected cells that would contribute to enhance the inflammatory response and cell damage both directly and indirectly, increasing procoagulant tissue factor and inflammatory cell adhesion and attraction proteins (E-selectine, ICAM,VCAM), as well as reducing $\mathrm{HO} / \mathrm{CO}$ or NOs that would contribute to vasocontriction, tissular hypoxia and underperfusion. The primarly inflammatory responses are driven by the innate immune system activation consisting in a massive invasion of neutrophils, monocytes and macrophages that release different proinflammatory cytokines and other proteins and molecules responsible to induce cell apoptosis and pyroptosis, leading to a different grade of tissue and organ damage. Simultaneoulsy, adaptive immune system comes on the scene through antigen-dependent lymphocyte activation by antigen presenting cells (APC) bearing viral antigenic peptides on human leukocyte antigens (HLA) molecules. APC-viral antigen complexes are recognized by virus-specific B and T cells (mainly CD8+) secreting, at different times, Th1 profile cytokines, which, reinforce previous inflammation, as well as Th2 adaptive humoral response by typical viral- induced pattern of neutralizing antibodies (Nab) IgM and IgG. In some cases, the appearance of Nab not only cannot limit viral replication, but trigger an hyperimmune response, owing to antibody dependent enhancement inflammatory pathways (ADE) that perpetuate responses from macrophages and Th1-lymphocyte, releasing a cytokine storm composed by IFN- $\alpha$, IFN- $\gamma$, IL- $1 \beta$, IL-2,IL-6, IL-12, IL-8, TNF- $\alpha$ etc. and more pro-inflammatory proteins like monocyte chemoattractant protein 1 (MCP1), macrophage inflammatory protein 1 alpha (MIP-1 $\alpha$ ), or MMP(tissue matrix metalloprotease). Additionally, these secondary inflammatory responses include antibody-dependent cell-mediated cytotoxicity, Ag-Ab immuncomplexes-mediated inflammatory pathways, including transient aPL-, and complement pathway hyperactivation that contributes to increasing tissue damage and hypoxia by releasing antiagiogenic factors (sFLT-1, sENG) and inducing platelet aggregation and clot cascade hiperactivation leading to thrombotic events

reduction or even viral clearance. The cessation of inflammation and further viral replication seems to be due to the generation of Th2-adaptive immune response, through neutralizing antibodies (Nab), which usually limits pulmonary phase $[24,25]$. 


\section{Secondary inflammatory responses. Hyperinflammatory phase. Stage 3}

In some cases, the appearance of Nab not only limits viral replication, but can also trigger a hyperimmune response. Antibody-dependent cellular cytotoxicity (ADCC) and complement pathway hyperactivation, contribute to an increase in tissue injury. In addition, both platelet and clot cascade hyperactivation give way to thrombotic events. The main underlying known mechanism, antibody-dependent enhancement (ADE), is able to up-modulate the immune response, regardless of virus triggering $[25,26]$. ADE perpetuates inflammatory responses from macrophages and Th1-lymphocyte by releasing a cytokine storm, composed of IFN- $\alpha$, IFN- $\gamma$, IL-1 $\beta$, IL-2,IL-6, IL-12, IL-18, IL-33, protein 10, monocyte chemoattractant protein 1 (MCP1), macrophage inflammatory protein 1 alpha (MIP-1 $\alpha$ ), and tumour necrosis factor-alpha (TNF- $\alpha$ ), among others [9, 10, 27]. This hyperinflammatory state can cause the host to suffer from a disseminated intravascular coagulation (DIC), in context of multi-organic failure that, in refractory catastrophic situations, result eventually in death [28].

\section{Immune protection. Post infectious phase. Stage 4}

The majority of infected patients are able to limit the situation and to overcome the disease. Thus, the underlying proinflammatory and clot pathway hyperactivation gradually returns to basal status. Clinically, this stage lasts 2-6 weeks, with some residual symptoms. Preliminary data suggest that at least $15-20 \%$ of cases with pulmonary or systemic involvement will have residual lesions, i.e., pulmonary fibrosis or heart conditions. Some dynamic models of SARS$\mathrm{CoV}-2$ assume that infection could induce immunity to reinfection for at least 1 year; although, the protective role of the immune response and the timescale of the protection, still remain unclear [29, 30]. Relapsing severe forms of COVID-19 patients have been reported, pointing out the question if the presence of naturally acquired antibodies against SARS-CoV-2, -or exposure to other previously coronaviruses- would bestow cross-protection or would be a harmful trigger through ADE in further contacts [31].

Considering the above, COVID-19 creates a great challenge to the immune system. The newness of SARS-CoV-2 makes all populations immunologically susceptible. Pregnant women, because of their particular and temporary immunological features, deserve special attention. The Fig. 2 represents all the hypothetical pathogenic pathways that could operate in a COVID-19 affected pregnancy.

\section{Covid-19 and pregnancy}

\section{Immunological and physiological characteristics of pregnancy}

Rather than immunosuppression, a successful pregnancy requires a robust, dynamic and responsive immune system [32]. The mother has to tolerate the implantation of a semiallogeneic or allogeneic foetus in the womb, while preserving the ability for protection against microbial challenges. A precise timing of local and systemic immunological events occurs throughout pregnancy [33].

At first, the embryo implantation and placentation benefit from a pro-inflammatory state; after that, an anti-inflammatory state permits cell clearance, angiogenesis, and fetal growth; and finally, a second pro-inflammatory state progressively prepares for the initiation of parturition in the third trimester until birth [32,33]. Overall, the events that facilitate immune tolerance, are led by hormonal inputs, i.e., human chorionic gonadotropin (hCG) and progesterone [34]. These events include indoleamine-2,3-dioxygenase (IDO) secretion by the placental trophoblast, the monocytemacrophages activation in decidua and the reduction of tryptophan catabolism [35]. Simultaneously, HLA-mediated recognition promotes the endogenous STAT5ab signalling across multiple $\mathrm{T}$ cell subsets, including Treg cells $(\mathrm{CD} 25+$ FoxP $3+)$, naive and memory CD $4+$ and $\mathrm{CD} 8+\mathrm{T}$ cells, and $\gamma \delta$ T cells.

Treg cells are crucial effectors, mostly but not only, in the peri-implantation period down-regulating the T-cell aggressive responses. Uterine NK (uNK) cells, which are non-cytotoxic but proangiogenic, accumulate in the decidua (15\% of all cell types), while decreasing in the maternal circulation $[36,37]$. They are activated by KIR receptors [38, 39]. The relationship between different maternal KIR genotypes and haplotypes and fetal HLA haplotypes, are crucial to tolerate the semiallogeneic fetus. On the other hand, the maternal innate immune system, through peripheral natural killer (pNK) cells, as well as monocytes and macrophages, will recognize and phagocytose eventual pathogens as a protective mechanism to systemic infections [40, 41]. Simultaneously, the systemic adaptive immune responses are down-regulated but keeps humoral Th2/cellular Th1 balanced, according to pro-inflammatory or anti-inflammatory pregnancy demands [33].

Besides the immunological aspects, physiologic maternal adaptations determine and increase susceptibility and severity of microbial infection throughout pregnancy [42, 43]. Oxygen consumption increases in pregnant women. The physiologic diaphragm elevation that prompts a restriction in lung expansion, as well as the hormone induced oedema of upper respiratory tract mucosa, render them highly sensitive 
to hypoxia and particularly vulnerable to respiratory pathogens [43].

Given this scenario, it is rational to think that any event, such as a highly immunogenic viral infection like SARSCoV-2, could interrupt the normal course of pregnancy. Some studies point to the involvement of COVID-19 in a deregulation of the Treg/Th17 cell ratio toward an increase in Th17 cells, resulting in uncontrolled systemic inflammation. Thus, in SARS-CoV-2-infected pregnant women, Treg/ Th17 cell imbalance might be potentially associated with adverse pregnancy outcomes such as pregnancy loss, preterm birth, and PE [44]. Different outcomes can be expected according to individual immune susceptibility and the gestational age at the onset of infection, which might bidirectionally determine both obstetric complications and duration, and/or severity of the infectious disease.

\section{Previous and current coronavirus infection experience in pregnant women}

SARS-CoV-2 infection in pregnant women could entail obstetric complications, and pregnancy can influence the course of the COVID-19 disease in the mother. Obstetric complications in COVID-19 could be induced by both direct viral effect (ACE2 receptors, viral replication) and the subsequent hyperinflammatory responses. There is current evidence suggesting that pregnant women have been specially affected by viral infections and suffer greater virus-associated morbidity and mortality than non-pregnant women [45].

Pneumonia arising from any infectious aetiology is an important cause of morbidity and mortality among pregnant women [46]. Classically, pneumonia was one of the most common causes of indirect maternal death [46, 47]. Mortality rate of the 1918 influenza pandemic was $26 \%$ of the general population, but $37 \%$ among pregnant women [48]. On the basis of data from twentieth century, approximately $25 \%$ of pregnant women with all-cause pneumonia will need to be hospitalized in intensive care units (ICU) and will require ventilatory support [47-50]. During the pandemic H1N1 influenza virus in 2009 pregnant women were, more than four times, more likely to be admitted to hospital than the general population [51].

Data from previous experiences in the SARS-CoV-1 and MERS-CoV epidemics, showed around 50\% of pregnant women who developed SARS were admitted to the ICU, and around $33 \%$ of them required mechanical ventilation with a mortality rate as high as $25 \%$ [52]. According to data from the first studies of COVID-19 in China amongst pregnant women, the clinical characteristics of pneumonia were similar to those of non-pregnant adult patients, with a prevalence of severe cases of $1-8 \%$ and a mortality rate of $1 \%[53,54]$. Certainly, current data show similar prevalence of mild and severe COVID-19 cases among pregnant women compared to general population. However, they advertise that pregnant women should be considered as a high risk group of pulmonary status worsening, mainly those cases with added comorbidities (asthma, obesity, diabetes) and during third trimester [55-59].

Regarding obstetric outcomes, previous studies showed that SARS-CoV-1 and MERS-CoV infections caused a higher incidence of maternal morbidity and poor obstetric outcomes such as preterm birth, IUGR, intrauterine death or neonatal death [60-63]. The first studies on perinatal morbidity and mortality and COVID-19 infection, reveal that all pregnant women, but mainly those in the third trimester, may be particularly vulnerable to suffer obstetric complications such as foetal loss, stillbirth, intrauterine growth restriction (IUGR) and preterm delivery [54, 63].These statements, however, should be taken with caution, as they come from a series of low numbered cases and retrospective case-control studies published mainly in China during the first wave of the pandemic.

One of the first systematic review and meta-analysis published on pregnancy outcomes in mothers infected with coronavirus (SARS-CoV-1, MERS-CoV and SARS-CoV-2), preterm birth was the most common adverse pregnancy outcome [64]. Foetal loss, pre-eclampsia (PE), caesarean section and perinatal death (7-11\%) were also more common, than in unaffected pregnancies. The mode of delivery in the majority of cases with pneumonia was caesarean section $(\sim 80 \%)[28,64]$. In that study, the authors warn that adverse outcomes when focusing on COVID-19 could be overestimated as a result of either a limited follow-up periods to recruit data, or misdiagnosis or iatrogenic acts due to the lack of experience in the clinical features of the novel virus [64]. A possible overestimation of the risk magnitude of obstetric complications in COVID-19 pregnancies could be partially related to the bias and the relative low level of evidence of first case reports and case series, published by a stressed scientific community, committed to publish clear data to provide knowledge to approach the overwhelming outbreak period of the pandemic. Since then, much data regarding the impact of COVID-19 in pregnancy has been accumulated [58, 65-67]. To date, data available about the consequences of COVID-19 in pregnancy outcomes state that preterm delivery and fetal distress are the main adverse outcomes observed in symptomatic COVID-19 pregnancies in the third trimester and at delivery [59,65-67]. The effects of SARS-CoV-2 in the first and second trimesters deserve specific studies to elucidate the controbution of the infection in complications such miscarriage, preeclampsia or IUGR showing variable and inconclusive incidence among published studies [65, 67-71]. 


\section{Hypothesis on the influence of SARS-CoV-2 infection in obstetric immune pathways}

\section{First and third trimester}

A state of mild systemic activation of the innate immune system and inflammation exists in the first but especially in the third trimester [72]. In these periods, an increased number of monocytes and granulocytes are found in maternal blood, releasing inflammatory cytokines, i.e., IL-8, TNFa, IL-6, by dendritic cells (DC), compared to non-pregnant women $[72,73]$. Cytokine storm has been documented as a key pathogenic immune mechanism in SARS-CoV-2 infection. The infection, therefore, could induce a more severe inflammatory state in pregnant women, that might explain an eventual higher incidence of first and third trimester outcomes like miscarriage [65, 74, 75], and preterm deliveries [76].

During the period from the third trimester to delivery, COVID-19 leads to an increased incidence of premature ropture of membranes, fetal distress and preterm labour [67, 76]. The higher incidence of these complications might be due both the need for reduce the mechanical limitation of thoracic expansion, and to improve maternal oxygenation, as well as the inflammatory response of the maternal multiorganic disease $[56,57,65,67]$.

\section{Second trimester}

During the second trimester, the low-level inflammatory state combined with skewing towards humoral immunity is thought to allow foetal growth. Th1 cell-mediated immunity is, somewhat compromised, increasing the susceptibility of pregnant women to viral and intracellular bacterial infections $[32,77]$. This scenario allows researchers to speculate on the effect of SARS-CoV-2 in shifting immune responses towards a rejection of the fetal-placental unit or even foetal compromise, resulting in variable manifestations of placental inflammation related diseases such as IUGR and PE [78-80], or foetal demise and foetal structural defects [81, 82]. The mother's response to infection tends to promote the fetus inflammatory response, which is defined as the fetal inflammatory response syndrome (FIRS) [83], characterized by high levels of inflammatory cytokines in placenta. These cytokines have been shown to affect the central nervous system and circulatory system and tend to cause fetal abnormal morphology in animal models, including ventricular expansion and bleeding [84, 85]. Even in human studies, a maintained hyperinflammatory environment during pregnancy would have a deleterious effect mostly on the neurodevelopment of the fetus, leading to potential neuronal dysfunctions in their postnatal life [86].
Despite SARS-CoV-2 virions have been detected in placental and foetal membranes [87, 88], the harm of the foetus in a COVID-19 pregnant mother is not expected to be exerted by a direct action of the virus, as vertical transmission in the amniotic fluid has not been clearly proved [54, 89-92]. A rang of $2 \%$ to $4 \%$ of pooled proportion of SARS-CoV-2 viral RNA test in neonatal nasopharyngeal swab resulted positive in recent published studies, even after having ensured no physical contact between the mother and the newborn. Despite the fact that not only nasopharyngeal swabs but umbilical cord, urine and rectal samples have tested positive suggesting a possible vertical transmission, no evidence of the presence of the virus in the amniotic fluid has been reported [92, 93].

An indirect foetal harm by immune responses induced by SARS-CoV-2 should not be excluded. For many viral diseases (SARS-CoV-1, MERS, influenza virus, Ebola virus, and Zika virus) it is well known that viral RNA can be detected in patients long after the disappearance of the virus. The immune system can neutralise viruses by lysing their envelope, aggregating virus particles; thus, the presence of nucleic acid alone, cannot be used to define viral shedding or infective potential, but could induce antibodies to be able to neutralise or enhance ADE [94]. ADE responses upregulating the immune-mediated cytokine storm described in severe and relapsing COVID-19 cases, have been similarly described in other positive ssRNA viruses, like flaviviruses such as Zika virus [95]. Recently, data of the human plasma with subneutralising antibody levels against flaviviruses with capacity to promote Zika virus pathogenicity in adult mice and foetal demise during pregnancy were reported [31, 96]. For these reasons, both foetuses and newborns of SARSCoV-2-infected mothers, should be accurately evaluated.

\section{Immune-thrombosis in COVID-19 pregnancies}

Immune-thrombotic mechanisms operate as the basis in almost all placental-related complications such as recurrent miscarriage (RM), abruptio placentae, placental insufficiency or foetal death. Pregnancy is a physiologically hypercoagulable state [97] with raised coagulation factors, including fibrinogen and FVIII, and markers of clot activation, i.e., D-dimer and decreased fibrinolytic proteins, such as protein $\mathrm{S}$ [97-99]. These particular conditions could be aggravated in an infectious context. Severe SARS-CoV-2 infection induces immune-mediated mechanisms, hypercoagulability and up-regulation of the complement pathway. Coagulopathy results from concurrent activation of the clot and fibrinolytic cascades, causing both thrombus and clotting factor consumption. Thus, manifestations can be either thrombotic or haemorrhagic. Venous and arterial thrombosis have been reported in both COVID-19 patients [100-102], and pregnant women [103]. Coagulopathy complications, 
thrombosis apart, have been reported similarly in pregnant women and in the general population [104]; however, pregnant women deserve closer surveillance since they are more likely to suffer from thrombotic-haemorrhagic catastrophic events [97, 98].

A quite low mortality rate has been reported since the COVID-19 outbreak [56, 65, 67, 105, 106]. Along with specific case series of maternal deaths [107, 108], a systematic review on maternal mortality summarizes that the acute respiratory distress syndrome (ARDS) and severity of pneumonia were considered as the leading causes of all maternal mortalities [58]. Except for some cases of maternal deaths related to thrombotic complications [58, 109], scarce publications has delved into a potencial implication of haemorragic o thrombotic events implicated in the referred COVID-19 maternal deaths. Microvascular thrombosis in the pulmonary system, -leaded by immunothrombosis phenomena-, and immobility due to hospitalization-associated venous thromboembolism are the two distinct mechanisms that could affect in those cases with a worst evolution of COVID-19 pregnant women [110-112]. Inflammation targeting, clot path way involvement and thrombosis should be investigated further in all maternal death cases $[106,110$, 113].

\section{Learning from placenta histology}

Despite being considerably scarce, valuable information comes from the histological analysis of the placentas of SARS-CoV-1 and SARS-CoV-2-infected mothers [114-116] that contributes to the understanding of the viral pathogenicity during pregnancy. In general terms, placentas of SARS-CoV-1 pregnancies infected during the first trimester of pregnancy were found to be normal. By contrast, those infected in the second or third trimester were clearly abnormal. Beyond acute or chronic signs of amniotic inflammation, the prevalent histopathological findings were marked signs of abnormal maternal vessels showing subchorionic and intervillous fibrin deposits, as well as extensive foetal thrombotic vasculopathy with areas of avascular chorionic villa, suggesting vascular malperfusion. A recent publication related to placental pathology of five full-term births to COVID-19 patients shows an histology indicative of fetal vascular malperfusion characterized by focal avascular villi and thrombi in larger fetal vessels [113].

Interestingly, villitis, the microscopic finding of inflammation of the chorionic villi that is the histologic hallmark of many maternal haematogenous infections transmitted through the placenta to the foetus [117], was not identified in these placentas. Overall, thrombotic and/or microangiophatic traits seemed to prevail over chorioamnionitic ones. Only in one reported case of second trimester miscarriage in a pregnant woman with SARS-CoV-2 infection [118], placental studies demonstrated mixed inflammatory infiltrates and unspecific increased intervillous fibrin deposition and funisitis; however, no bacteria or fungi were identified in placental PCR or cultures.

Histological findings in SARS-CoV-1 and SARS-CoV-2 placentae share some characteristics with those of pregnant women with obstetric antiphospholipid syndrome (OAPS) [119]. Therefore, COVID-19 infection and the presence of aPL might have a synergistic effect, inducing both inflammation and thrombosis. Antiphospholipid syndrome (APS) is considered a prothrombotic disorder [120]; however, in OAPS subset, rather than thrombotic, the main pathogenic mechanisms triggered by aPL are those related with inflammation [79-81]. Moreover, viral infections as a trigger to synthesize aPL has already been reported $[121,122]$. Acute viral infections can be frequent triggers of catastrophic antiphospholipid syndrome (CAPS) (24\%) [123, 124], an infrequent and severe clinical subset of APS presenting in $\leq 1 \%$ of cases. Only one paper has been published regarding aPL in the context of severe COVID-19 disease [125]. Similarly, other cases have also been recruited (Esteve-Valverde E, Alijotas-Reig J: unpublished results). Some argue that transient non-pro-thrombotic antibodies can arise in patients with critical illness and various infections. It is difficult to dismiss their potential harmful effect in severe medical conditions, like severe COVID-19, that present similar characteristics as CAPS. Recently, a European Multicentre Registry endorsed by the EUROFORUM projects to recruit cases of COVID-19 patients with thrombosis and aPL positivity (COVIDAPS) has been started (Alijotas-Reig $\mathrm{J}$ : personal communication).

\section{Complement system role}

\section{Complement role in COVID-19}

The complement system is a protein-composed mediator -(C1 to C9)- of the innate immune system that promotes inflammation, defends against bacterial infections, and often neutralizes infectious viruses [126]. Its classical pathway is triggered by $\mathrm{Ag}-\mathrm{Ab}$ complexes, and its alternative pathway by specific surface antigens and molecules. Other activators such as coagulation factors FXa, FXIa and plasmin, that can cleave both $\mathrm{C} 5$ and $\mathrm{C} 3$, have been reported [127]. These pathways converge on a common via. The common pathway includes production of $\mathrm{C} 3 \mathrm{a}$ and $\mathrm{C} 5 \mathrm{a}$ inflammatory mediators, $\mathrm{C} 3 \mathrm{~b}$-initiated pathogen opsonisation, and ends in formation of the C5b-9 membrane attack complex (MAC) that lyses targeted cells, resulting in cell death [128, 129]. Complement activation has polarized effects: towards protective-tolerogeneic-defender functions or life-threatening responses, like in autoimmune diseases such as systemic lupus erythematosus (SLE) or rheumatoid arthritis (RA) 
[129]. The complement system role in the pathogenicity of previous coronavirus epidemic diseases has already been described. In SARS-CoV-1-infected mice lacking C3, thus unable to activate the common complement pathway, a less severe respiratory dysfunction was observed, as well as lower cytokine levels despite equal viral loads [129]. Similarly, in the murine model of MERS-CoV infection, increased levels of C5a and C5b-9 were found in sera and lungs of sick mice $[130,131]$. When blocking C5a protein with specific antibodies, an improvement of lung damage besides lower cytokine production and viral replication were seen [132]. According to all these data, hyperactivation of the complement system in SARS-CoV-2 infection, as a powerful inducer of the hyperinflammatory state, could be compellingly suggested [131, 132]. Widespread complement activation, with $\mathrm{C} 3$ deposition in lung biopsies and increased C5a serum levels of COVID-19 patients have already been reported [133]. Excessive complement activation is clearly recognized to be involved in diffuse thrombotic microangiopathy, as seen in organ dysfunction syndromes such as atypical haemolytic uremic syndrome (aHUS), thrombotic thrombocytopenic purpura (TTP) and CAPS [134-136]. Likewise, in other well-known hyperinflammatory and hyperferritinaemic disorders, -see Table 1-, like haemophagocytic syndrome (HPS) and macrophage activation syndrome (MAS), a hyperactivation of the complement system has also been recognized to be essential to induce tissue damage [137-139]. The current similarities between these syndromes and the severe life-threatening COVID-19 forms, reinforce the role of complement hyperactivation as one of the most harmful molecular pathways in the pathogenesis of the disease.

Table 1 Hyperferritinemia-related disorders

Adult Still's disease
Systemic lupus erythematosus
Vasculitis
Lymphoma
Catastrophic antiphospholipid syndrome
Biological compound anti-CD ${ }^{\mathrm{a}}$-28 treatment
Haemophagocytic syndrome
Macrophage activation syndrome
SARS-CoV-2 infection (COVID-19)

SARS-CoV-2 severe acute respiratory syndrome related to coronavirus-2

COVID-19 coronavirus disease 2019

${ }^{\text {a }}$ Cluster differentiation

\section{Complement role in pregnancy}

Autoantibody-mediated complement pathway hyperactivation, has been widely described in several pregnancy complications [140-142]. Thus, besides strategic HLA-G exposition, T cells suppression and uNK-specific activity, a tight regulation of complement system activation is essentially needed to achieve a successful tolerant environmental in the fetal-maternal interface [143, 144]. The specific role of C1q, synthesised in extravillous trophoblast, and widely distributed in human decidua, has been studied [145]. To achieve a simultaneous balanced control between required inflammation and immune-protection against infection, trophoblast secrete C3a, C4a, and C5a [146, 147]. This regulation necessarily involves placental complement inhibitors, such as decay-accelerating factor (DAF) and membrane cofactor protein $(\mathrm{MCP})$, that are expressed throughout gestation, protecting from preterm delivery among other adverse events [148, 149]. The opposite scenario appears when uncontrolled complement activation, -conditioned by gene polymorphism, (mainly in sperm genes) [150, 151], ethnicity, acquired mutations $[152,153]$, infections or presence of aPL [154, 155]-, determines disabling placental immune regulation, leading to abnormal pregnancy outcomes like RM, IUGR, or PE.

Preterm birth Studies in mice models of preterm birth, reported high C5a deposits and macrophage releasing MMP, collagen degradation and increased cervical distensibility after an administration of low-dose intravaginal endotoxin. These observations were reverted after progesterone treatment. Activation of complement entail uterotonic properties that have been tested through C5a- C5aR interaction, leading to preterm birth [156]. By contrast, the labour at term is not mediated by inflammatory molecules and cells or complement activation, but by MMP and other active products released from cervical fibroblasts and columnar epithelial cells [157].

In addition to immaturity-related risks of preterm birth, both inflammatory and/or infectious insults that can occur during pregnancy have deleterious effects on the foetus. Several studies show a strong association between intrauterine inflammation or infection and the following complement hyperactivation, causing foetal and newborn brain abnormalities and neuronal injuries, respectively $[158,159]$. Some illustrative studies in mice models demonstrated that the length of axons of cortical neurons of preterm mice exposed to C5a deposits was considerably reduced, compared with controls [160].

Preeclampsia Pre-eclampsia is another obstetric disorder where complement activation appears to play an important 
role. Despite an open discussion on the role of circulating complement levels to predict obstetric outcomes [161-164], complement component tissue deposits have been observed in embryo implantation sites of pre-eclamptic mice models, and in focal or diffuse staining patterns in the placentae of women with PE and IUGR [165-167].The complement hyperactivation acts as a strong inflammatory insult, leading to functional deficiency of free vascular endothelial growth factor (VEGF) while increasing levels of soluble VEGF receptor 1 (sVEGFR-1, or sFlt-1), a strong anti-angiogenic molecule, enhancing organ underperfusion and defective placental development [168-170], which have been proved to be the origin of Preeclampsia [171-173]. A clear restoration of this essential angiogenic imbalance, (reducing sFlt-1 as well as increasing VEGF), has been observed after complement inhibition treatment $[169,174]$.

Preeclampsia is a disease characterized by increased levels of anti-angiogenic factors sensitive to hypoxia produced by the placenta to the detriment of angiogenic ones [172, 173, 175]. However, the diagnostic criteria is still based on clinical and laboratory data, and not includes these biochemical markers. Several disorders have previously proved to imitate PE from clinical and analytical point of view, including COVID-19 [176]. Recent studies have reported $\mathrm{PE} / \mathrm{Hellp}$ factures in pregnant women with severe forms of COVID-19 despite showing a normal angiogenic status and placental perfusion $[68,71]$. The role of the inflammatory pathways triggered by the virus should be investigated in these specific cases.

Recurrent miscarriage. Recurrent miscarriage in obstetric antiphospholipid syndrome In previous studies, up to $20 \%$ of miscarriages and fetal losses not mediated by autoantibodies were associated with hypocomplementemia [177]. According to the newest data, the main role of complement-mediated injuries in trophoblast and placenta causing embryo or foetal loss, is thought to be through aPL [154, 155, 178, 179]. Murine models have widely demonstrated the hyperactivation of complement in both pro-inflammatory and pro-thrombotic events involved in obstetric complications seen in OAPS [155, 179], where the main clinical outcomes are RM, foetal death, PE, premature births or IUGR [178, 180, 181]. Using human or animal aPL monoclonal antibodies, the increased foetal death and embryo resorption seen in transferred pregnant mice were attributed to hyperactivation of the classical complement pathway acting as key mediators of foetal injury. Complement activation (via C3a, C5a, and MAC) cooperates not only in triggering a local inflammatory process, but eventually, leading to placental thrombosis [141, 142, 180], through stimulus of the expression of tissue factor (TF) or CD142, a powerful activator of extrinsic clot cascade [179]. The usefulness of therapeutic molecules aimed to complement inactivation in human models reinforces the complement roles in many human obstetric immune-mediated diseases [182-184].

\section{Complement pathway and its hypothesized role in COVID-19 pregnancies}

Considering the endothelial injury as a hallmark of COVID-19, SARS-CoV-2 infection during pregnancy could induce or even aggravate complement activation, involving obstetric complications like RM or PE. As previously mentioned, microangiophatic syndromes, such as aHUS, TTP, acute fatty liver of pregnancy (AFLP) or CAPS, can complicate pregnancy. All these syndromes share common pathogenic mechanisms like vasospasm, platelet activation or destruction, microvascular thrombosis, endothelial cell dysfunction, and reduced tissue perfusion [176]. Some of them have been identified in severe COVID-19 cases. Therefore we can infer that, in the context of the SARS-CoV-2 pandemic, COVID-19 disease might be considered a potential cause of placental-related disorders, and even become part of the list of PE imitators [176], challenging physicians and specialists to be faced with difficult differential diagnosis see Table 2.

\section{Role of ACE2 and RAS in COVID-19 pregnancies}

\section{Role of ACE2 in pregnancy}

RAS has a major role in regulation of vascular tone and cardiovascular haemodinamics. RAS has two main metabolic axis from angiotensinogen to angiotensin I, showing opposite effects: ACE1/angiotensin II (AngII) axis, and ACE2/

Table 2 Preeclampsia imitators

HELLP syndrome

Acute fatty liver of pregnancy

Systemic lupus erythematosus with nephritis

Catastrophic antiphospholipid syndrome

Renal thrombotic microangiopathy related to aPL

Systemic vasculitis

Systemic sclerosis: renal crisis

Thrombotic thrombocytopenic purpura

Atypical hemolityc uremic syndrome

Sepsis

Disseminated viral diseases, i.e. herpes virus, CMV. SARS-CoV-2

Drugs: gemcitabine; quinidine, cyclosporine A, thienopyridines

Others: necrotizing pancreatitis, pheocromocytoma, cocaine abuse, paroxysmal nocturnal hemoglobinuria

$a P L$ antiphospholipid antibodies, HELLP haemolysis, elevated liver enzymes, low platelet count, $C M V$ cytomegalovirus, SARS-CoV-2 severe acute respiratory syndrome related to coronavirus-2 
angiotensin 1-7 (Ang 1-7) axis [185].While AngII can induce strong vasoconstriction and proinflammatory effects, Ang (1-7) exhibits antiproliferative, antiapoptotic, and mild vasodilation abilities contributing to cardiovascular protective effects, including anti-heart failure, antithrombotic and/ or anti-myocardial hypertrophy, and also attenuating vascular dysfunction related to metabolic syndrome [185, 186]. A balanced RAS activation is one of the cornerstones of the haemodynamic regulation during pregnancy, while contributing to maintain a normal, or even decreased blood pressure, in a progressive increasing volaemia [187]. In normal pregnancy, estrogenic influence induces a shift in metabolic pathways of angiotensin peptides in a tissue-specific manner. A physiological enhancement of ACE2 increases the expression of the vasodilator Ang (1-7) [188-190]; this effect counteracts the elevation of tissue and circulating Ang II levels leading to a vasoconstrictor effect, while amplifying a vasodilator component [191].

The vasodilator actions of Ang (1-7) have not only been reported in vascular beds of systemic maternal circulation, but in feto-maternal interface, thereby releasing nitric oxide, kinins, and prostaglandins [192].Studies in both human and mice models have demonstrated a wide and dynamic expression of RAS effectors in maternal-fetal interface. In early gestation, pro-renin receptor and the AngII type 1 receptor (AT1R) have been localized in extravillous trophoblast cells, suggesting a balancing role in trophoblast migration [192-194], while correlating with a high expression of VEGF [194]. These findings, along with the expression of ACE2 in syncytiotrophoblasts and Ang 1-7 releasing into the fetal-maternal vascular endothelium, targeting maternal, placental and foetal vessels in a dynamic process throughout pregnancy, suggest that the RAS regulation pathway to be likely important in both placental angiogenesis and maintained maternal vascular tone [194-196].

All RAS components, both systemic and tissue-based (renal and uteroplacental) are involved in hypertensive disorders during pregnancy [197]. A dysregulation of systemic and renal RAS, results in cardiovascular dysfunction and electrolyte imbalance as well as variable PE syndrome showing hypertension, o edema and proteinuria [197, 198]. In abnormal placentation, the situation is aggravated due to the hypersecretion of RAS proteins/angiotensin (Ang) peptides, particles, and RAS mRNAs of the ischaemic and undeperfused placenta [196, 197]. In addition, an underlying autoimmune/alloimmune phenomena have been described through autoantibodies like $\mathrm{AT}_{1} \mathrm{R}-\mathrm{AAs}$, that emulate Ang II actions, thus increasing inflammation and vasoconstriction [199]. Animal models have shown that $\mathrm{AT}_{1} \mathrm{R}$-AAs increase sensitivity to AngII and are able to activate complement C3aR pathways that release antiangiogenic factors, such as sFlt-1 [174, 199] that increase placental oxidative stress, endothelial dysfunction, vascular reactivity, and angiogenic imbalance. All these phenomena are the primary mechanisms in placental related diseases, like early and severe PE, and IUGR $[173,200]$. RAS peptides and $\mathrm{AT}_{1}$ R-AAs were only seen if clinical PE was present (late-onset hypertension and proteinuria), but not in early stages of the disease, suggesting a later- clinical role of RAS imbalance, rather than an early-genesis role of PE [201].

\section{Hypothesized role of ACE2 and RAS in COVID-19 pregnancies}

Differences in ACE2 expression could correlate with a different susceptibility to SARS-CoV-1 infection [202], and therefore, to SARS-CoV-2 displaying COVID-19 in different forms of severity. The expression levels of ACE2/TMPRSS2 among fetal-maternal interface, may vary among pregnancy [203]. SARS-CoV-2 could trigger RAS dysfunctions when ACE2 binds during pregnancy, causing variable organ injuries [204-207] -as seen in other adult patients-, as well as in placenta, due to systemic haemodynamic disturbances. This occurs not only in the mother, but also in the fetus [165], since ACE2 is expressed in fetal endothelial cells and fetal organs too. ACE 2 is present in the fetal heart, liver and lungs, but not in the kidneys. This fact could explain the observation that SARS-CoV-2 is not excreted in urine, and thus, unable to detect viral RNA in amniotic fluid [54, 208].

SARS-CoV-2 induced downregulation and shedding of ACE2 reducing Ang 1-7, could have a non-despicable role in some trophoblast/placental or haemodynamic-related obstetric complications such as miscarriage or PE, respectively. While some studies reported a higher incidence of miscarriage and PE among COVID-19 pregnant women compared to the general population [54, 64, 209], others concluded that there is not an increased risk of obstetric complications [173, 200]. Generally, on the basis of current data, many authors argue with weak evidence of a causal association between SARS-CoV-2 infection and obstetric complications, stating that further investigations are needed. Hypertension, kidney disease, thrombocytopenia or liver injury are frequently seen in moderate to severe COVID19 cases [205, 206, 210, 211]. If they occur during pregnancy, patients could fulfill complete or incomplete clinical and/or laboratory PE or HELLP syndrome criteria [71]. To make a true diagnosis, deeper investigation should be executed, and thus, an appropriate care management [71, 200, 212, 213]. 


\section{Role of natriuretic peptides B-type natriuretic peptide (BNP) and its $\mathrm{N}$-terminal fragment (NT- proBNP)}

\section{Role of NT-proBNP in COVID-19}

B-type natriuretic peptide (BNP) and its N-terminal fragment (NT-proBNP) are natural inhibitors of RAS and the sympathetic nervous system (SNS). The main, but not only source of BNP, is ventricular myocardium. BNP is synthesized as a prehormone (proBNP) cleaved in circulation into the active BNP, and the inactive NT-proBNP [214]. The main stimulus for increased BNP and NT-proBNP is myocardial wall stress, as a result of an adaptive mechanism to cardiac walls elongation after variations of haemodynamic parameters, to prevent cardiac insufficiency. The physiological effects of BNP are manifold and comprise natriuresis/ diuresis and induce peripheral vasodilatation. NT-proBNP has a greater half-life with higher serum values, and thus, becomes a better marker for any relevant cardiac overload in chronic heart failure. Between 8-28\% of COVID-19 patients show evidence of cardiac injury with elevated troponin and natriuretic peptides $[204,215]$. Some data support NTproBNP as an independent risk factor for in-hospital death in patients with severe COVID-19 disease [216]. The predictive value of increased BNP and NT-proBNP in plasma was already recognized as cardiovascular endpoints in patients and all-cause death in the general population [217].

\section{NT-proBNP in pregnancy and in COVID-19 pregnancies}

Corin,- the type II transmembrane serine protease enzyme that is in charge of cleaving with proBNP in BNP and NTproBNP-, has been expressed mainly in the heart and in the pregnant uterus [218]. In mice models, both delayed trophoblast invasion and impaired spiral artery remodeling, as well as high blood pressure and proteinuria, were found in pregnant rats lacking corin. There is an association of NT- proBNP levels with RAS component levels in pregnant women [219]. Some studies have focused on the increased circulating levels of natriuretic peptides in pregnant women suffering from PE, mainly in its early and severe form [219-221]. PE involves a failure of the maternal cardiovascular system to adapt to the demands of pregnancy, therefore a cardiac origin of NT-proNBP was first attributed. Considering that PE is mainly a placental mediated disease, in which an inflamed and undeperfused placenta release diverse antiangiogenic factors into the maternal circulation (sFlt1, soluble Endoglin (sENG) [173, 200], the hypothesis of a partial placental origin of the elevated levels of BNP/ NT-proBNP was first suspected, and further confirmed, when NT-proBNP protein was observed in maternal spiral arteries and in syncytiotrophoblasts, in preeclamptic placental samples [222]. Interestingly, some antiangiogenic factors present in women with PE have also been observed in non-pregnant women suffering from myocardial diseases [175]. Many authors, therefore, have studied the potential cardiovascular strain of PE, and its repercussion in cardiovascular morbidity and mortality in later life [223, 224]. The potential use of natriuretic peptides such as NT-proBNP in the assessment of hypertensive pregnancy disorders, is due to cardiovascular alterations that have been considered to have a non-despicable role in their physiopathology. As PE is mainly an angiogenic inflammatory disorder, current evidence supports that NT-proBNP could be useful to assess a cardiovascular strain but, on contrary to antiangiogenic factors (sFlt1, sENG), does not seem to improve the diagnostic of PE [225]. Data from severe COVID-19 patients show that increased levels of NT-proNBP could be related to cardiac and renal injury, and systemic inflammation [175]. The significance of increased levels of NT-proBNP in COVID-19 pregnant patients has not yet been evaluated. Given that, higher NT- proBPN levels should be outlined in pregnant women, mainly in those affected with moderate-severe COVID-19, showing PE or PE like syndrome, to establish their role as a current cardiac stress marker, or even as a marker for the risk of cardiovascular repercussion later in life.

\section{Final remarks}

The global strike of the COVID-19 pandemic has challenged the scientific community with a struggle to understand the complexity of its pathophysiological mechanisms. The whole population is susceptible to sicken. Pregnant women, however, deserve particular attention. Severe COVID-19 is mainly an immune-mediated disorder triggered by the SARS-CoV-2 infection that, in context of pregnancy could bring about several complications. Not only those related to lung and multiorganic damage, but also placental injury, mainly due to an excessive hyperinflammation and, frequently, hypercoagulation owing to thrombosis. Immunethrombosis contains a wide spectrum of pathological mechanisms that have been proven to be involved in the aetiology of many placental-related disorders such as RM, PE, IUGR or preterm birth. Pathogenetic mechanisms of pregnancy complications such as complement activation, release of pro-inflammatory cytokines, antigen-antibody abnormal responses, prothrombotic phenomena or endothelial-vascular dysregulation are similar to those involved in immunemediated severe forms of COVID-19. Given that SARSCoV-2 has come to stay, obstetricians and immunologists, as well as all medical specialists, should be encouraged to keep collecting disease outcomes in the context of pregnancy, to elucidate the potential harmful responses to SARS-CoV-2 
and /or other coronavirus infections, as well as research on actual bidirectional interactions between COVID-19 and pregnancy, that can interfere with their respective outcomes.

Acknowledgments The authors thank Erika Bokor for reviewing and correcting the English style and grammar of the manuscript, as well as all the physicians, researchers, scientists and health workers who have been struggling and still the COVID-19 pandemia all around the world.

Authors' contribution Raquel Ferrer-Oliveras: project development, design and draft of the work, data collection and data analysis, manuscript writing and editing, critical revision of the final content. Manel Mendoza: manuscript writing and editing, critical revision of the final content. Sira Capote: data collection and data analysis. Laia Pratcorona: data collection and data analysis. Enrique Esteve-Valverde: data collection and data analysis. Lluis Cabero- Roura: critical revision of the final content. Jaume Alijotas-Reig: manuscript writing and editing, critical revision of the final content. All authors have approved the final version of the manuscript.

Funding The authors stated that ONAGRUP (Barcelona, Spain) is supporting the research work of Systemic Autoimmune Research Unit of Vall d'Hebron Research Institute.

\section{Declarations}

Conflict of interest Raquel Ferrer-Oliveras declares that she has no conflict of interest. Manel Mendoza declares that he has no conflict of interest. Sira Capote declares that she has no conflict of interest. Laia Pratcorona declares that she has no conflict of interest. Enrique EsteveValverde declares that he has no conflict of interest. Lluis Cabero- Roura declares that he has no conflict of interest. Jaume Alijotas-Reig declares that he has no conflict of interest.

Informed Consent Not applicable.

Ethical approval This article does not contain any studies with human participants or animals performed by any of the authors.

\section{References}

1. Huang Y, Tu M, Wang S et al (2020) Clinical characteristics of laboratory confirmed positive cases of SARS-CoV-2 infection in Wuhan, China: a retrospective single center analysis. Travel Med Infect Dis. https://doi.org/10.1016/j.tmaid.2020.101606

2. WHO Director-General's opening remarks at the media briefing on COVID-19 - 11 March 2020. https://www.who.int/dg/speec hes/detail/who-director-general-s-opening-remarks-at-the-mediabriefing-on-covid-19---11-march-2020. Accessed 5 May 2020

3. Chen N, Zhou M, Dong X et al (2020) Epidemiological and clinical characteristics of 99 cases of 2019 novel coronavirus pneumonia in Wuhan, China: a descriptive study. Lancet 395:507513. https://doi.org/10.1016/S0140-6736(20)30211-7

4. Lu R, Zhao X, Li J et al (2020) Genomic characterisation and epidemiology of 2019 novel coronavirus: implications for virus origins and receptor binding. Lancet 395:565-574. https://doi. org/10.1016/S0140-6736(20)30251-8

5. Song Z, Xu Y, Bao L et al (2019) From SARS to MERS thrusting coronaviruses into the spotlight. Viruses. https://doi.org/10.3390/ v11010059
6. Wang D, Hu B, Hu C et al (2020) Clinical Characteristics of 138 Hospitalized Patients With 2019 Novel Coronavirus-Infected Pneumonia in Wuhan. JAMA, China. https://doi.org/10.1001/ jama.2020.1585

7. Fu Y, Cheng Y, Wu Y (2020) Understanding SARS-CoV2-Mediated inflammatory responses: from mechanisms to potential therapeutic tools. Virol Sin. https://doi.org/10.1007/ s12250-020-00207-4

8. Guo Y-R, Cao Q-D, Hong Z-S et al (2020) The origin, transmission and clinical therapies on coronavirus disease 2019 (COVID19) outbreak - an update on the status. Mil Med Res 7:11. https:// doi.org/10.1186/s40779-020-00240-0

9. Huang C, Wang Y, Li X et al (2020) Clinical features of patients infected with 2019 novel coronavirus in Wuhan, China. Lancet 395:497-506. https://doi.org/10.1016/S0140-6736(20)30183-5

10. Mehta P, McAuley DF, Brown M et al (2020) COVID-19: consider cytokine storm syndromes and immunosuppression. Lancet 395:1033-1034. https://doi.org/10.1016/S0140-6736(20)30628-0

11. Li W, Moore MJ, Vasilieva N et al (2003) Angiotensin-converting enzyme 2 is a functional receptor for the SARS coronavirus. Nature 426:450-454. https://doi.org/10.1038/nature02145

12. Xie X, Xudong X, Chen J et al (2006) Age- and gender-related difference of ACE2 expression in rat lung. Life Sci 78:21662171. https://doi.org/10.1016/j.lfs.2005.09.038

13. Clarke NE, Turner AJ (2012) Angiotensin-converting enzyme 2: the first decade. Int J Hypertens 2012:307315. https://doi.org/10. $1155 / 2012 / 307315$

14. Perlman S, Netland J (2009) Coronaviruses post-SARS: update on replication and pathogenesis. Nat Rev Microbiol 7:439-450. https://doi.org/10.1038/nrmicro2147

15. Hui DS (2017) Epidemic and emerging coronaviruses (severe acute respiratory syndrome and middle east respiratory syndrome). Clin Chest Med 38:71-86. https://doi.org/10.1016/j. ccm.2016.11.007

16. Tang X, Wu C, Li X et al (2020) On the origin and continuing evolution of SARS-CoV-2. Natl Sci Rev. https://doi.org/10.1093/ nsr/nwaa036

17. Read JM, Bridgen JR, Cummings DA et al (2020) Novel coronavirus 2019-nCoV: early estimation of epidemiological parameters and epidemic predictions. Infect Dis 13:134-138

18. Ivashkiv LB, Donlin LT (2014) Regulation of type I interferon responses. Nat Rev Immunol 14:36-49. https://doi.org/10.1038/ nri3581

19. Prompetchara E, Ketloy C, Palaga T (2020) Immune responses in COVID-19 and potential vaccines: lessons learned from SARS and MERS epidemic. Asian Pac J Allergy Immunol 38:1-9. https://doi.org/10.12932/AP-200220-0772

20. Conti P, Ronconi G, Caraffa A et al (2020) Induction of proinflammatory cytokines (IL-1 and IL-6) and lung inflammation by Coronavirus-19 (COVI-19 or SARS-CoV-2): anti-inflammatory strategies. J Biol Regul Homeost Agents 34(2):327-331. https://doi.org/10.23812/CONTI-E

21. Li X, Geng M, Peng Y et al (2020) Molecular immune pathogenesis and diagnosis of COVID-19. J Pharm Anal. https://doi.org/ 10.1016/j.jpha.2020.03.001

22. Guo J, Huang Z, Lin L, Lv J (2020) Coronavirus Disease 2019 (COVID-19) and cardiovascular disease: a viewpoint on the potential influence of angiotensin-converting enzyme inhibitors/ angiotensin receptor blockers on onset and severity of severe acute respiratory syndrome coronavirus 2 infection. J Am Heart Assoc 9:e016219. https://doi.org/10.1161/JAHA.120.016219

23. Imai Y, Kuba K, Rao S et al (2005) Angiotensin-converting enzyme 2 protects from severe acute lung failure. Nature 436:112-116. https://doi.org/10.1038/nature03712

24. Peiris JSM, Chu CM, Cheng VCC et al (2003) Clinical progression and viral load in a community outbreak of 
coronavirus-associated SARS pneumonia: a prospective study. Lancet 361:1767-1772. https://doi.org/10.1016/s01406736(03)13412-5

25. Yang Z, Werner HC, Kong W et al (2005) Evasion of antibody neutralization in emerging severe acute respiratory syndrome coronaviruses. Proc Natl Acad Sci USA 102:797-801. https:// doi.org/10.1073/pnas.0409065102

26. Tetro JA (2020) Is COVID-19 receiving ADE from other coronaviruses? Microbes Infect 22:72-73. https://doi.org/10.1016/j. micinf.2020.02.006

27. Yang M (2020) Cell Pyroptosis, a Potential Pathogenic Mechanism of 2019-nCoV Infection. Social Science Research Network, Rochester

28. Chen T, Wu D, Chen $\mathrm{H}$ et al (2020) Clinical characteristics of 113 deceased patients with coronavirus disease 2019: retrospective study. BMJ 368:m1091. https://doi.org/10.1136/bmj. m1091

29. Reed SE (1984) The behaviour of recent isolates of human respiratory coronavirus in vitro and in volunteers: evidence of heterogeneity among 229E-related strains. J Med Virol 13:179-192. https://doi.org/10.1002/jmv.1890130208

30. Callow KA, Parry HF, Sergeant M, Tyrrell DA (1990) The time course of the immune response to experimental coronavirus infection of man. Epidemiol Infect 105:435-446. https://doi. org/10.1017/s0950268800048019

31. Huang AT, Garcia-Carreras B, Hitchings MDT et al (2020) A systematic review of antibody mediated immunity to coronaviruses: antibody kinetics, correlates of protection, and association of antibody responses with severity of disease. Infectious Diseases (except HIV/AIDS). Nat Commun. 11(1):4704. https://doi.org/10.1038/s41467-020-18450-4

32. Mor G, Aldo P, Alvero AB (2017) The unique immunological and microbial aspects of pregnancy. Nat Rev Immunol 17:469482. https://doi.org/10.1038/nri.2017.64

33. Aghaeepour N, Ganio EA, Mcilwain D et al (2017) An immune clock of human pregnancy. Sci Immunol 2:eaan2946

34. Schumacher A, Brachwitz N, Sohr S et al (2009) Human chorionic gonadotropin attracts regulatory $\mathrm{T}$ cells into the fetalmaternal interface during early human pregnancy. J Immunol 182:5488-5497. https://doi.org/10.4049/jimmunol.0803177

35. Munn DH, Zhou M, Attwood JT et al (1998) Prevention of allogeneic fetal rejection by tryptophan catabolism. Science 281:1191-1193. https://doi.org/10.1126/science.281.5380. 1191

36. Tilburgs T, Roelen DL, van der Mast BJ et al (2008) Evidence for a selective migration of fetus-specific $\mathrm{CD} 4+\mathrm{CD} 25$ bright regulatory $\mathrm{T}$ cells from the peripheral blood to the decidua in human pregnancy. J Immunol 180:5737-5745. https://doi.org/10.4049/ jimmunol.180.8.5737

37. Guerin LR, Prins JR, Robertson SA (2009) Regulatory T-cells and immune tolerance in pregnancy: a new target for infertility treatment? Hum Reprod Update 15:517-535. https://doi.org/10. 1093/humupd/dmp004

38. Trowsdale J, Betz AG (2006) Mother's little helpers: mechanisms of maternal-fetal tolerance. Nat Immunol 7:241-246. https://doi. org/10.1038/ni1317

39. Moffett A, Colucci F (2014) Uterine NK cells: active regulators at the maternal-fetal interface. J Clin Invest 124:1872-1879. https://doi.org/10.1172/JCI68107

40. Heikkinen J, Möttönen M, Alanen A, Lassila O (2004) Phenotypic characterization of regulatory $\mathrm{T}$ cells in the human decidua. Clin Exp Immunol 136:373-378. https://doi.org/10.1111/j.13652249.2004.02441.x

41. Aluvihare VR, Kallikourdis M, Betz AG (2004) Regulatory $\mathrm{T}$ cells mediate maternal tolerance to the fetus. Nat Immunol 5:266-271. https://doi.org/10.1038/ni1037
42. Luo Y, Yin K (2020) Management of pregnant women infected with COVID-19. Lancet Infect Dis 20:513-514. https://doi.org/ 10.1016/S1473-3099(20)30191-2

43. Liu H, Wang L-L, Zhao S-J et al (2020) Why are pregnant women susceptible to COVID-19? An immunological viewpoint. J Reprod Immunol 139:103122. https://doi.org/10. 1016/j.jri.2020.103122

44. Muyayalo KP, Huang D-H, Zhao S-J et al (2020) COVID-19 and Treg/Th17 imbalance: potential relationship to pregnancy outcomes. Am J Reprod Immunol 84:e13304. https://doi.org/ 10.1111/aji.13304

45. Racicot K, Mor G (2017) Risks associated with viral infections during pregnancy. J Clin Invest 127:1591-1599. https://doi. org/10.1172/JCI87490

46. Benedetti TJ, Valle R, Ledger WJ (1982) Antepartum pneumonia in pregnancy. Am J Obstet Gynecol 144:413-417. https:// doi.org/10.1016/0002-9378(82)90246-0

47. Berkowitz K, LaSala A (1990) Risk factors associated with the increasing prevalence of pneumonia during pregnancy. Am J Obstet Gynecol 163:981-985. https://doi.org/10.1016/00029378(90)91109-p

48. Gottfredsson M (2008) The Spanish flu in Iceland 1918. Lessons in medicine and history. Laeknabladid 94:737-745

49. Madinger NE, Greenspoon JS, Ellrodt AG (1989) Pneumonia during pregnancy: has modern technology improved maternal and fetal outcome? Am J Obstet Gynecol 161:657-662. https:// doi.org/10.1016/0002-9378(89)90373-6

50. Visscher HC, Visscher RD (1971) Indirect obstetric deaths in the state of Michigan 1960-1968. Am J Obstet Gynecol 109:1187-1196. https://doi.org/10.1016/0002-9378(71) 90664-8

51. Jamieson DJ, Honein MA, Rasmussen SA et al (2009) H1N1 2009 influenza virus infection during pregnancy in the USA. Lancet 374:451-458. https://doi.org/10.1016/S0140-6736(09) 61304-0

52. Wong SF, Chow KM, Leung TN et al (2004) Pregnancy and perinatal outcomes of women with severe acute respiratory syndrome. Am J Obstet Gynecol 191:292-297. https://doi.org/10. 1016/j.ajog.2003.11.019

53. Report of the WHO-China Joint Mission on Coronavirus Disease 2019 (COVID-19). https://www.who.int/publications-detail/ report-of-the-who-china-joint-mission-on-coronavirus-disease2019-(covid-19). Accessed 5 May 2020

54. Chen H, Guo J, Wang C et al (2020) Clinical characteristics and intrauterine vertical transmission potential of COVID-19 infection in nine pregnant women: a retrospective review of medical records. Lancet 395:809-815. https://doi.org/10.1016/S01406736(20)30360-3

55. Lokken EM, Walker CL, Delaney S et al (2020) Clinical characteristics of 46 pregnant women with a SARS-CoV-2 infection in Washington State. Am J Obstet Gynecol. https://doi.org/10. 1016/j.ajog.2020.05.031

56. Breslin N, Baptiste C, Gyamfi-Bannerman C et al (2020) Coronavirus disease 2019 infection among asymptomatic and symptomatic pregnant women: two weeks of confirmed presentations to an affiliated pair of New York City hospitals. Am J Obstet Gynecol MFM 2:100118. https://doi.org/10.1016/j.ajogmf.2020. 100118

57. Andrikopoulou M, Madden N, Wen T et al (2020) Symptoms and critical illness among obstetric patients with coronavirus disease 2019 (COVID-19) infection. Obstet Gynecol 136:291-299. https://doi.org/10.1097/AOG.0000000000003996

58. Hessami K, Homayoon N, Hashemi A et al (2020) COVID-19 and maternal, fetal and neonatal mortality: a systematic review. J Matern Fetal Neonatal Med. https://doi.org/10.1080/14767058. 2020.1806817 
59. Allotey J, Stallings E, Bonet M et al (2020) Clinical manifestations, risk factors, and maternal and perinatal outcomes of coronavirus disease 2019 in pregnancy: living systematic review and meta-analysis. BMJ 370:m3320. https://doi.org/10. 1136/bmj.m3320

60. Lam CM, Wong SF, Leung TN et al (2004) A case-controlled study comparing clinical course and outcomes of pregnant and non-pregnant women with severe acute respiratory syndrome. BJOG 111:771-774. https://doi.org/10.1111/j.1471-0528.2004. 00199.x

61. Schwartz DA, Graham AL (2020) Potential maternal and infant outcomes from (Wuhan) coronavirus 2019-nCoV infecting pregnant women: lessons from SARS, MERS, and other human coronavirus infections. Viruses. https://doi.org/10.3390/v1202 0194

62. Perlman S (2020) Another decade, another coronavirus. N Engl J Med 382:760-762. https://doi.org/10.1056/NEJMe2001126

63. Hui DSC, Zumla A (2019) Severe acute respiratory syndrome: historical, epidemiologic, and clinical features. Infect Dis Clin North Am 33:869-889. https://doi.org/10.1016/j.idc.2019.07. 001

64. Di Mascio D, Khalil A, Saccone G et al (2020) Outcome of Coronavirus spectrum infections (SARS, MERS, COVID 1-19) during pregnancy: a systematic review and meta-analysis. Am J Obstet Gynecol MFM. https://doi.org/10.1016/j.ajogmf.2020. 100107

65. Juan J, Gil MM, Rong Z et al (2020) Effect of coronavirus disease 2019 (COVID-19) on maternal, perinatal and neonatal outcome: systematic review. Ultrasound Obstet Gynecol 56:15-27. https:// doi.org/10.1002/uog.22088

66. Akhtar H, Patel C, Abuelgasim E, Harky A (2020) COVID-19 (SARS-CoV-2) infection in pregnancy: a systematic review. Gynecol Obstet Invest 85:295-306. https://doi.org/10.1159/ 000509290

67. Crovetto F, Crispi F, Llurba E et al (2021) Impact of SARSCoV-2 infection on pregnancy outcomes: a population-based study. Clin Infect Dis. https://doi.org/10.1093/cid/ciab104

68. Figueras F, Llurba E, Martinez-Portilla R et al (2020) COVID19 causing HELLP-like syndrome in pregnancy and role of angiogenic factors for differential diagnosis. Obstetrics Gynecol $56: 257-258$

69. Di Toro F, Gjoka M, Di Lorenzo G et al (2021) Impact of COVID-19 on maternal and neonatal outcomes: a systematic review and meta-analysis. Clin Microbiol Infect 27:36-46. https://doi.org/10.1016/j.cmi.2020.10.007

70. Wang C-L, Liu Y-Y, Wu C-H et al (2021) Impact of COVID-19 on Pregnancy. Int J Med Sci 18:763-767. https://doi.org/10.7150/ ijms.49923

71. Mendoza M, Garcia-Ruiz I, Maiz N et al (2020) Preeclampsialike syndrome induced by severe COVID-19: a prospective observational study. BJOG 127(11):1374-1380. https://doi.org/ 10.1111/1471-0528.16339

72. Messerli M, May K, Hansson SR et al (2010) Feto-maternal interactions in pregnancies: placental microparticles activate peripheral blood monocytes. Placenta 31:106-112. https://doi. org/10.1016/j.placenta.2009.11.011

73. Wegmann TG, Lin H, Guilbert L, Mosmann TR (1993) Bidirectional cytokine interactions in the maternal-fetal relationship: is successful pregnancy a TH2 phenomenon? Immunol Today 14:353-356. https://doi.org/10.1016/0167-5699(93)90235-D

74. Yan J, Guo J, Fan C et al (2020) Coronavirus disease 2019 (COVID-19) in pregnant women: a report based on 116 cases. Am J Obstet Gynecol. https://doi.org/10.1016/j.ajog.2020.04.014

75. Chen L, Li Q, Zheng D et al (2020) Clinical characteristics of pregnant women with Covid-19 in Wuhan. China N Engl J Med 382:e100. https://doi.org/10.1056/NEJMc2009226
76. Rajewska A, Mikołajek-Bedner W, Lebdowicz-Knul J et al (2020) COVID-19 and pregnancy-where are we now? A review. J Perinat Med 48:428-434. https://doi.org/10.1515/jpm-2020-0132

77. Kumpel BM, Manoussaka MS (2012) Placental immunology and maternal alloimmune responses. Vox Sang 102:2-12. https://doi. org/10.1111/j.1423-0410.2011.01533.x

78. Al-Azemi M, Raghupathy R, Azizieh F (2017) Pro-inflammatory and anti-inflammatory cytokine profiles in fetal growth restriction. Clin Exp Obstet Gynecol 44:98-103

79. Mullins E, Prior T, Roberts I, Kumar S (2012) Changes in the maternal cytokine profile in pregnancies complicated by fetal growth restriction. Am J Reprod Immunol 68:1-7. https://doi. org/10.1111/j.1600-0897.2012.01132.x

80. Ribeiro VR, Romao-Veiga M, Romagnoli GG et al (2017) Association between cytokine profile and transcription factors produced by T-cell subsets in early- and late-onset pre-eclampsia. Immunology 152:163-173. https://doi.org/10.1111/imm.12757

81. Matthiesen L, Berg G, Ernerudh J, Skogh T (1995) Lymphocyte subsets and autoantibodies in pregnancies complicated by placental disorders. Am J Reprod Immunol 33:31-39. https://doi. org/10.1111/j.1600-0897.1995.tb01135.x

82. Kalagiri RR, Carder T, Choudhury $S$ et al (2016) Inflammation in complicated pregnancy and its outcome. Am J Perinatol 33:1337-1356. https://doi.org/10.1055/s-0036-1582397

83. Gotsch F, Romero R, Kusanovic JP et al (2007) The fetal inflammatory response syndrome. Clin Obstet Gynecol 50:652-683. https://doi.org/10.1097/GRF.0b013e31811ebef6

84. Davies JK, Shikes RH, Sze CI et al (2000) Histologic inflammation in the maternal and fetal compartments in a rabbit model of acute intra-amniotic infection. Am J Obstet Gynecol 183:10881093. https://doi.org/10.1067/mob.2000.108888

85. Madsen-Bouterse SA, Romero R, Tarca AL et al (2010) The transcriptome of the fetal inflammatory response syndrome. Am J Reprod Immunol 63:73-92. https://doi.org/10.1111/j.1600-0897. 2009.00791.x

86. Werenberg Dreier J, Nybo Andersen A-M, Hvolby A et al (2016) Fever and infections in pregnancy and risk of attention deficit/ hyperactivity disorder in the offspring. J Child Psychol Psychiatry 57:540-548. https://doi.org/10.1111/jcpp.12480

87. Algarroba GN, Rekawek P, Vahanian SA et al (2020) Visualization of SARS-CoV-2 virus invading the human placenta using electron microscopy. Am J Obstet Gynecol. 223(2):275-278. https://doi.org/10.1016/j.ajog.2020.05.023

88. Penfield CA, Brubaker SG, Limaye MA et al (2020) Detection of SARS-COV-2 in placental and fetal membrane samples. Am J Obstet Gynecol MFM. 2(3):100133. https://doi.org/10.1016/j. ajogmf.2020.100133

89. Yang Z, Liu Y (2020) Vertical transmission of severe acute respiratory syndrome coronavirus 2: a systematic review. Am J Perinatol. 37(10):1055-1060. https://doi.org/10.1055/s-0040-17121 61

90. Alzamora MC, Paredes T, Caceres D et al (2020) Severe COVID19 during pregnancy and possible vertical transmission. Am J Perinatol 37:861-865. https://doi.org/10.1055/s-0040-1710050

91. Deniz M, Tezer H (2020) Vertical transmission of SARS CoV-2: a systematic review. J Matern Fetal Neonatal Med. https://doi. org/10.1080/14767058.2020.1793322

92. Kotlyar AM, Grechukhina O, Chen A et al (2021) Vertical transmission of coronavirus disease 2019: a systematic review and meta-analysis. Am J Obstet Gynecol 224:35-53.e3. https://doi. org/10.1016/j.ajog.2020.07.049

93. Rubio Lorente AM, Pola Guillén M, López Jimenez N et al (2020) Study of amniotic fluid in pregnant women infected with SARS-CoV-2 in first and second trimester. Is there evidence of vertical transmission? J Matern Fetal Neonatal Med. https://doi. org/10.1080/14767058.2020.1811669 
94. Atkinson B, Petersen E (2020) SARS-CoV-2 shedding and infectivity. Lancet 395:1339-1340. https://doi.org/10.1016/S01406736(20)30868-0

95. Priyamvada L, Suthar MS, Ahmed R, Wrammert J (2017) Humoral immune responses against zika virus infection and the importance of preexisting flavivirus immunity. J Infect Dis 216:S906-S911. https://doi.org/10.1093/infdis/jix513

96. Shim B-S, Kwon Y-C, Ricciardi MJ et al (2019) Zika virusimmune plasmas from symptomatic and asymptomatic individuals enhance zika pathogenesis in adult and pregnant mice. MBio. https://doi.org/10.1128/mBio.00758-19

97. Abbassi-Ghanavati M, Greer LG, Cunningham FG (2009) Pregnancy and laboratory studies: a reference table for clinicians. Obstet Gynecol 114:1326-1331. https://doi.org/10.1097/AOG. 0b013e3181c2bde 8

98. Vlachodimitropoulou Koumoutsea E, Vivanti AJ, Shehata N et al (2020) COVID19 and acute coagulopathy in pregnancy. J Thromb Haemost. https://doi.org/10.1111/jth.14856

99. Greer IA (1999) Thrombosis in pregnancy: maternal and fetal issues. Lancet 353:1258-1265. https://doi.org/10.1016/S01406736(98)10265-9

100. Mei H, Hu Y (2020) Characteristics, causes, diagnosis and treatment of coagulation dysfunction in patients with COVID-19. Zhonghua Xue Ye Xue Za Zhi 41(3):185-191. https://doi.org/ 10.3760/cma.j.issn.0253-2727.2020.0002

101. Zhou F, Yu T, Du R et al (2020) Clinical course and risk factors for mortality of adult inpatients with COVID-19 in Wuhan, China: a retrospective cohort study. Lancet 395:1054-1062. https://doi.org/10.1016/S0140-6736(20)30566-3

102. Tang N, Bai H, Chen $X$ et al (2020) Anticoagulant treatment is associated with decreased mortality in severe coronavirus disease 2019 patients with coagulopathy. J Thromb Haemost 18:10941099. https://doi.org/10.1111/jth.14817

103. Othman M, Santamaría Ortiz A, Cerdá M et al (2019) Thrombosis and hemostasis health in pregnancy: registries from the International Society on Thrombosis and Haemostasis. Res Pract Thromb Haemost 3:607-614. https://doi.org/10.1002/rth2.12243

104. Dashraath P, Wong JLJ, Lim MXK et al (2020) Coronavirus disease 2019 (COVID-19) pandemic and pregnancy. Am J Obstet Gynecol. https://doi.org/10.1016/j.ajog.2020.03.021

105. WAPM (World Association of Perinatal Medicine) Working Group on COVID-19 (2021) Maternal and perinatal outcomes of pregnant women with SARS-CoV-2 infection. Ultrasound Obstet Gynecol 57:232-241. https://doi.org/10.1002/uog.23107

106. Kadir RA, Kobayashi T, Iba T et al (2020) COVID-19 coagulopathy in pregnancy: critical review, preliminary recommendations, and ISTH registry-Communication from the ISTH SSC for Women's Health. J Thromb Haemost 18:3086-3098. https://doi. org $/ 10.1111 /$ jth. 15072

107. Takemoto MLS, Menezes MO, Andreucci CB et al (2020) Maternal mortality and COVID-19. J Matern Fetal Neonatal Med. https://doi.org/10.1080/14767058.2020.1786056

108. Hantoushzadeh S, Shamshirsaz AA, Aleyasin A et al (2020) Maternal death due to COVID-19. Am J Obstet Gynecol 223:109.e1-109.e16. https://doi.org/10.1016/j.ajog.2020.04.030

109. Ahmed I, Azhar A, Eltaweel N, Tan BK (2020) First COVID-19 maternal mortality in the UK associated with thrombotic complications. Br J Haematol 190:e37-e38. https://doi.org/10.1111/ bjh. 16849

110. D’Souza R, Malhamé I, Teshler L et al (2020) A critical review of the pathophysiology of thrombotic complications and clinical practice recommendations for thromboprophylaxis in pregnant patients with COVID-19. Acta Obstet Gynecol Scand 99:1110 1120. https://doi.org/10.1111/aogs.13962
111. Martinelli I, Ferrazzi E, Ciavarella A et al (2020) Pulmonary embolism in a young pregnant woman with COVID-19. Thromb Res 191:36-37. https://doi.org/10.1016/j.thromres.2020.04.022

112. Ahmed S, Zimba O, Gasparyan AY (2020) Thrombosis in Coronavirus disease 2019 (COVID-19) through the prism of Virchow's triad. Clin Rheumatol 39:2529-2543. https://doi.org/10. 1007/s10067-020-05275-1

113. Mulvey JJ, Magro CM, Ma LX et al (2020) Analysis of complement deposition and viral RNA in placentas of COVID-19 patients. Ann Diagn Pathol 46:151530. https://doi.org/10.1016/j. anndiagpath.2020.151530

114. Ng WF, Wong SF, Lam A et al (2006) The placentas of patients with severe acute respiratory syndrome: a pathophysiological evaluation. Pathology 38:210-218. https://doi.org/10.1080/00313 020600696280

115. Shanes ED, Mithal LB, Otero S et al (2020) Placental pathology in COVID-19 Pathology. Am J Clin Pathol. 154:23-32

116. Mulvey JJ, Magro CM, Ma LX et al (2020) A mechanistic analysis placental intravascular thrombus formation in COVID-19 Patients. In: Annals of diagnostic pathology. https://pubmed.ncbi. nlm.nih.gov/32361635/?from_term $=$ sars-cov- $2+$ in +placenta\& from_page $=2 \&$ from $\_$pos $=5$. Accessed 29 May 2020

117. Kim CJ, Romero R, Chaemsaithong P et al (2015) Acute chorioamnionitis and funisitis: definition, pathologic features, and clinical significance. Am J Obstet Gynecol 213:S29-52. https:// doi.org/10.1016/j.ajog.2015.08.040

118. Baud D, Greub G, Favre G et al (2020) Second-Trimester miscarriage in a pregnant woman With SARS-CoV-2 infection. JAMA. https://doi.org/10.1001/jama.2020.7233

119. Viall CA, Chamley LW (2015) Histopathology in the placentae of women with antiphospholipid antibodies: a systematic review of the literature. Autoimmun Rev 14:446-471. https://doi.org/10. 1016/j.autrev.2015.01.008

120. Cavazzana I, Andreoli L, Limper M et al (2018) Update on antiphospholipid syndrome: ten topics in 2017. Curr Rheumatol Rep 20:15. https://doi.org/10.1007/s11926-018-0718-4

121. Shoenfeld Y, Blank M, Cervera R et al (2006) Infectious origin of the antiphospholipid syndrome. Ann Rheum Dis 65:2-6. https:// doi.org/10.1136/ard.2005.045443

122. Abdel-Wahab N, Talathi S, Lopez-Olivo MA, Suarez-Almazor ME (2018) Risk of developing antiphospholipid antibodies following viral infection: a systematic review and meta-analysis. Lupus 27:572-583. https://doi.org/10.1177/0961203317731532

123. Asherson RA, Cervera R, Piette JC et al (2001) Catastrophic antiphospholipid syndrome: clues to the pathogenesis from a series of 80 patients. Medicine 80:355-377. https://doi.org/10. 1097/00005792-200111000-00002

124. Uthman IW, Gharavi AE (2002) Viral infections and antiphospholipid antibodies. Semin Arthritis Rheum 31:256-263. https:// doi.org/10.1053/sarh.2002.28303

125. Zhang Y, Xiao M, Zhang S et al (2020) Coagulopathy and antiphospholipid antibodies in patients with Covid-19. N Engl J Med 382:e38. https://doi.org/10.1056/NEJMc2007575

126. Dunkelberger JR, Song W-C (2010) Complement and its role in innate and adaptive immune responses. Cell Res 20:34-50. https://doi.org/10.1038/cr.2009.139

127. Amara U, Flierl MA, Rittirsch D et al (2010) Molecular intercommunication between the complement and coagulation systems. J Immunol 185:5628-5636. https://doi.org/10.4049/jimmu nol.0903678

128. Gralinski LE, Sheahan TP, Morrison TE et al (2018) Complement activation contributes to severe acute respiratory syndrome coronavirus pathogenesis. MBio. https://doi.org/10.1128/mBio. 01753-18 
129. Nauta AJ, Roos A, Daha MR (2004) A regulatory role for complement in innate immunity and autoimmunity. Int Arch Allergy Immunol 134:310-323. https://doi.org/10.1159/000079261

130. Wang R, Xiao H, Guo R et al (2015) The role of C5a in acute lung injury induced by highly pathogenic viral infections. Emerg Microbes Infect 4:e28. https://doi.org/10.1038/emi.2015.28

131. Jiang Y, Zhao G, Song N et al (2018) Blockade of the C5a-C5aR axis alleviates lung damage in hDPP4-transgenic mice infected with MERS-CoV. Emerg Microbes Infect 7:77. https://doi.org/ 10.1038/s41426-018-0063-8

132. Risitano AM, Mastellos DC, Huber-Lang M, et al (2020) Complement as a target in COVID-19? Nat Rev Immunol. 2020;20(6):343-344. doi: https://doi.org/10.1038/s41577-0200320-7. Epub 2020 Apr 23. Erratum in: Nat Rev Immunol. 2020;20(7):448. PMID: 32327719; PMCID: PMC7187144.

133. Gao T, Hu M, Zhang X, et al (2020) Highly pathogenic coronavirus $\mathrm{N}$ protein aggravates lung injury by MASP-2-mediated complement over-activation. Infectious Diseases (except HIV/ AIDS)

134. Kello N, Khoury LE, Marder G et al (2019) Secondary thrombotic microangiopathy in systemic lupus erythematosus and antiphospholipid syndrome, the role of complement and use of eculizumab: case series and review of literature. Semin Arthritis Rheum 49:74-83. https://doi.org/10.1016/j.semarthrit.2018.11. 005

135. Zheng L, Zhang D, Cao W et al (2019) Synergistic effects of ADAMTS13 deficiency and complement activation in pathogenesis of thrombotic microangiopathy. Blood 134:1095-1105. https://doi.org/10.1182/blood.2019001040

136. Raina R, Krishnappa V, Blaha T et al (2019) Atypical hemolyticuremic syndrome: an update on pathophysiology, diagnosis, and treatment. Ther Apher Dial 23:4-21. https://doi.org/10.1111/ 1744-9987.12763

137. Al-Samkari H, Berliner N (2018) Hemophagocytic Lymphohistiocytosis. Annu Rev Pathol 13:27-49. https://doi.org/10.1146/ annurev-pathol-020117-043625

138. Shoenfeld Y (2020) Corona (COVID-19) time musings: Our involvement in COVID-19 pathogenesis, diagnosis, treatment and vaccine planning. Autoimmun Rev. 19(6):102538. https:// doi.org/10.1016/j.autrev.2020.102538

139. Alijotas-Reig J, Esteve-Valverde E, Belizna C et al (2020) Immunomodulatory therapy for the management of severe COVID-19. Beyond the anti-viral therapy: a comprehensive review. Autoimmun Rev. https://doi.org/10.1016/j.autrev.2020.102569

140. Girardi G, Bulla R, Salmon JE, Tedesco F (2006) The complement system in the pathophysiology of pregnancy. Mol Immunol 43:68-77. https://doi.org/10.1016/j.molimm.2005.06.017

141. Tincani A, Cavazzana I, Ziglioli T et al (2010) Complement activation and pregnancy failure. Clin Rev Allergy Immunol 39:153-159. https://doi.org/10.1007/s12016-009-8183-5

142. Girardi G (2018) Complement activation, a threat to pregnancy. Semin Immunopathol 40:103-111. https://doi.org/10.1007/ s00281-017-0645-X

143. Holmes CH, Simpson KL, Wainwright SD et al (1990) Preferential expression of the complement regulatory protein decay accelerating factor at the fetomaternal interface during human pregnancy. J Immunol 144:3099-3105

144. Hsi BL, Hunt JS, Atkinson JP (1991) Differential expression of complement regulatory proteins on subpopulations of human trophoblast cells. J Reprod Immunol 19:209-223. https://doi.org/ 10.1016/0165-0378(91)90036-p

145. Agostinis C, Bulla R, Tripodo C et al (2010) An alternative role of $\mathrm{C} 1 \mathrm{q}$ in cell migration and tissue remodeling: contribution to trophoblast invasion and placental development. J Immunol 185:4420-4429. https://doi.org/10.4049/jimmunol.0903215
146. Bulla R, Bossi F, Agostinis C et al (2009) Complement production by trophoblast cells at the feto-maternal interface. J Reprod Immunol 82:119-125. https://doi.org/10.1016/j.jri.2009.06.124

147. Mor G, Cardenas I, Abrahams V, Guller S (2011) Inflammation and pregnancy: the role of the immune system at the implantation site. Ann NY Acad Sci 1221:80-87. https://doi.org/10.1111/j. 1749-6632.2010.05938.x

148. Morgan BP, Meri S (1994) Membrane proteins that protect against complement lysis. Springer Semin Immunopathol 15:369-396. https://doi.org/10.1007/BF01837366

149. Mao D, Wu X, Deppong C et al (2003) Negligible role of antibodies and C5 in pregnancy loss associated exclusively with C3-dependent mechanisms through complement alternative pathway. Immunity 19:813-822. https://doi.org/10.1016/s10747613(03)00321-2

150. Abdi-Shayan S, Monfaredan A, Moradi Z et al (2016) Association of CD46 IVS1-1724 C $>$ G single nucleotide polymorphism in iranian women with unexplained recurrent spontaneous abortion (URSA). Iran J Allergy Asthma Immunol 15:303-308

151. Risk JM, Flanagan BF, Johnson PM (1991) Polymorphism of the human CD46 gene in normal individuals and in recurrent spontaneous abortion. Hum Immunol 30:162-167. https://doi. org/10.1016/0198-8859(91)90030-d

152. Salmon JE, Heuser C, Triebwasser M et al (2011) Mutations in complement regulatory proteins predispose to preeclampsia: a genetic analysis of the PROMISSE cohort. PLoS Med 8:e1001013. https://doi.org/10.1371/journal.pmed.1001013

153. Lokki AI, Aalto-Viljakainen T, Meri S et al (2015) Genetic analysis of membrane cofactor protein (CD46) of the complement system in women with and without preeclamptic pregnancies. PLoS ONE 10:e0117840. https://doi.org/10.1371/journal.pone. 0117840

154. Salmon JE, Girardi G (2007) Theodore E. Woodward Award: antiphospholipid syndrome revisited: a disorder initiated by inflammation. Trans Am Clin Climatol Assoc 118:99-114

155. Girardi G, Berman J, Redecha P et al (2003) Complement C5a receptors and neutrophils mediate fetal injury in the antiphospholipid syndrome. J Clin Invest 112:1644-1654. https://doi.org/10. 1172/JCI18817

156. Gonzalez JM, Franzke C-W, Yang F et al (2011) Complement activation triggers metalloproteinases release inducing cervical remodeling and preterm birth in mice. Am J Pathol 179:838-849. https://doi.org/10.1016/j.ajpath.2011.04.024

157. Gonzalez JM, Dong Z, Romero R, Girardi G (2011) Cervical remodeling/ripening at term and preterm delivery: the same mechanism initiated by different mediators and different effector cells. PLoS ONE 6:e26877. https://doi.org/10.1371/journal. pone. 0026877

158. Rathbone R, Counsell SJ, Kapellou O et al (2011) Perinatal cortical growth and childhood neurocognitive abilities. Neurology 77:1510-1517. https://doi.org/10.1212/WNL.0b013e3182 $33 \mathrm{~b} 215$

159. Bell MJ, Hallenbeck JM (2002) Effects of intrauterine inflammation on developing rat brain. J Neurosci Res 70:570-579. https:// doi.org/10.1002/jnr.10423

160. Pedroni SMA, Gonzalez JM, Wade J et al (2014) Complement inhibition and statins prevent fetal brain cortical abnormalities in a mouse model of preterm birth. Biochim Biophys Acta 1842:107-115. https://doi.org/10.1016/j.bbadis.2013.10.011

161. Derzsy Z, Prohászka Z, Rigó J et al (2010) Activation of the complement system in normal pregnancy and preeclampsia. Mol Immunol 47:1500-1506. https://doi.org/10.1016/j.molimm.2010. 01.021

162. Soto E, Romero R, Richani K et al (2010) Preeclampsia and pregnancies with small-for-gestational age neonates have different 
profiles of complement split products. J Matern Fetal Neonatal Med 23:646-657. https://doi.org/10.3109/14767050903301009

163. Tabacco S, Giannini A, Garufi C et al (2019) Complementemia in pregnancies with antiphospholipid syndrome. Lupus 28:15031509. https://doi.org/10.1177/0961203319882507

164. Buyon JP, Kim MY, Guerra MM et al (2015) Predictors of pregnancy outcomes in patients with lupus: a cohort study. Ann Intern Med 163:153-163. https://doi.org/10.7326/M14-2235

165. Petitbarat M, Durigutto $P$, Macor $P$ et al (2015) Critical role and therapeutic control of the lectin pathway of complement activation in an abortion-prone mouse mating. J Immunol 195:56025607. https://doi.org/10.4049/jimmunol.1501361

166. Kim EN, Yoon BH, Lee JY et al (2015) Placental C4d deposition is a feature of defective placentation: observations in cases of preeclampsia and miscarriage. Virchows Arch 466:717-725. https://doi.org/10.1007/s00428-015-1759-y

167. Buurma A, Cohen D, Veraar K et al (2012) Preeclampsia is characterized by placental complement dysregulation. Hypertension 60:1332-1337. https://doi.org/10.1161/HYPERTENSIONAHA. 112.194324

168. Girardi G, Yarilin D, Thurman JM, et al (2006) Complement activation induces dysregulation of angiogenic factors and causes fetal rejection and growth restriction. In: The Journal of experimental medicine. https://pubmed.ncbi.nlm.nih.gov/16923853/? from_term $=+$ Complement+activation+induced+dysregulation + of + angiogenic + factors + and + causes + fetal+rejection + and + growth+restriction\&from_pos $=1$. Accessed 9 May 2020

169. Ahmed A, Singh J, Khan Y et al (2010) A new mouse model to explore therapies for preeclampsia. PLoS ONE 5:e13663. https:// doi.org/10.1371/journal.pone.0013663

170. Banadakoppa M, Balakrishnan M, Yallampalli C (2018) Upregulation and release of soluble fms-like tyrosine kinase receptor 1 mediated by complement activation in human syncytiotrophoblast cells. Am J Reprod Immunol 80:e13033. https://doi.org/ 10.1111/aji.13033

171. Herraiz I, Llurba E, Verlohren S et al (2018) Update on the Diagnosis and prognosis of preeclampsia with the aid of the sFlt-1/ PIGF ratio in singleton pregnancies. Fetal Diagn Ther 43:81-89. https://doi.org/10.1159/000477903

172. Levine RJ, Maynard SE, Qian C et al (2004) Circulating angiogenic factors and the risk of preeclampsia. N Engl J Med 350:672-683. https://doi.org/10.1056/NEJMoa031884

173. Llurba E, Crispi F, Verlohren S (2015) Update on the pathophysiological implications and clinical role of angiogenic factors in pregnancy. Fetal Diagn Ther 37:81-92. https://doi.org/10.1159/ 000368605

174. Xia Y, Kellems RE (2013) Angiotensin receptor agonistic autoantibodies and hypertension: preeclampsia and beyond. Circ Res 113:78-87. https://doi.org/10.1161/CIRCRESAHA.113.300752

175. Zeisler H, Llurba E, Chantraine F et al (2016) Predictive value of the sFlt-1:PlGF ratio in women with suspected preeclampsia. N Engl J Med 374:13-22. https://doi.org/10.1056/NEJMoa1414 838

176. Sibai BM (2009) Imitators of severe pre-eclampsia. Semin Perinatol 33:196-205. https://doi.org/10.1053/j.semperi.2009.02.004

177. Tichenor JR, Bledsoe LB, Opsahl MS, Cunningham DS (1995) Activation of complement in humans with a first-trimester pregnancy loss. Gynecol Obstet Invest 39:79-82. https://doi.org/10. $1159 / 000292384$

178. Esteve-Valverde E, Ferrer-Oliveras R, Alijotas-Reig J (2016) Obstetric antiphospholipid syndrome. Rev Clin Esp 216:135145. https://doi.org/10.1016/j.rce.2015.09.003

179. Redecha P, Franzke C-W, Ruf W et al (2008) Neutrophil activation by the tissue factor/Factor VIIa/PAR2 axis mediates fetal death in a mouse model of antiphospholipid syndrome. J Clin Invest 118:3453-3461. https://doi.org/10.1172/JCI36089
180. Meroni PL, Borghi MO, Grossi C et al (2018) Obstetric and vascular antiphospholipid syndrome: same antibodies but different diseases? Nat Rev Rheumatol 14:433-440. https://doi.org/10. 1038/s41584-018-0032-6

181. Alijotas-Reig J, Esteve-Valverde E, Ferrer-Oliveras R et al (2019) The European registry on obstetric antiphospholipid syndrome (EUROAPS): a survey of 1000 consecutive cases. Autoimmun Rev 18:406-414. https://doi.org/10.1016/j.autrev.2018.12.006

182. Gustavsen A, Skattum L, Bergseth G et al (2017) Effect on mother and child of eculizumab given before caesarean section in a patient with severe antiphospholipid syndrome: a case report. Medicine 96:e6338. https://doi.org/10.1097/MD.0000000000 006338

183. Burwick RM, Feinberg BB (2013) Eculizumab for the treatment of preeclampsia/HELLP syndrome. Placenta 34:201-203. https:// doi.org/10.1016/j.placenta.2012.11.014

184. Kim MY, Guerra MM, Kaplowitz E et al (2018) Complement activation predicts adverse pregnancy outcome in patients with systemic lupus erythematosus and/or antiphospholipid antibodies. Ann Rheum Dis 77:549-555. https://doi.org/10.1136/annrh eumdis-2017-212224

185. Santos RAS, Sampaio WO, Alzamora AC et al (2018) The ACE2/Angiotensin-(1-7)/MAS axis of the renin-angiotensin system: focus on angiotensin-(1-7). Physiol Rev 98:505-553. https://doi.org/10.1152/physrev.00023.2016

186. Li XC, Zhang J, Zhuo JL (2017) The vasoprotective axes of the renin-angiotensin system: physiological relevance and therapeutic implications in cardiovascular, hypertensive and kidney diseases. Pharmacol Res 125:21-38. https://doi.org/10.1016/j. phrs.2017.06.005

187. Lumbers ER, Pringle KG (2014) Roles of the circulating reninangiotensin-aldosterone system in human pregnancy. Am J Physiol Regul Integr Comp Physiol 306:R91-101. https://doi.org/10. 1152/ajpregu.00034.2013

188. Oelkers WK (1996) Effects of estrogens and progestogens on the renin-aldosterone system and blood pressure. Steroids 61:166171. https://doi.org/10.1016/0039-128x(96)00007-4

189. Chen YF, Naftilan AJ, Oparil S (1992) Androgen-dependent angiotensinogen and renin messenger RNA expression in hypertensive rats. Hypertension 19:456-463. https://doi.org/10.1161/ 01.hyp.19.5.456

190. Li P, Ferrario CM, Ganten D, Brosnihan KB (1997) Chronic estrogen treatment in female transgenic (mRen2) 27 hypertensive rats augments endothelium-derived nitric oxide release. Am J Hypertens 10:662-670. https://doi.org/10.1016/s0895-7061(97) 00039-3

191. Ferrario CM, Chappell MC, Tallant EA et al (1997) Counterregulatory actions of angiotensin-(1-7). Hypertension 30:535-541. https://doi.org/10.1161/01.hyp.30.3.535

192. Brosnihan K, Neves L, Anton L et al (2004) Enhanced expression of Ang-(1-7) during pregnancy. Brazilian J Med Biol Res 37:1255-1262. https://doi.org/10.1590/S0100-879X200400 0800017

193. Brosnihan KB, Li P, Ferrario CM (1996) Angiotensin-(1-7) dilates canine coronary arteries through kinins and nitric oxide. Hypertension 27:523-528. https://doi.org/10.1161/01.hyp.27.3. 523

194. Pringle KG, Tadros MA, Callister RJ, Lumbers ER (2011) The expression and localization of the human placental prorenin/ renin-angiotensin system throughout pregnancy: roles in trophoblast invasion and angiogenesis? Placenta 32:956-962. https:// doi.org/10.1016/j.placenta.2011.09.020

195. Gennari-Moser C, Khankin EV, Escher G et al (2013) Vascular endothelial growth factor-A and aldosterone: relevance to normal pregnancy and preeclampsia. Hypertension 61:1111-1117. https://doi.org/10.1161/HYPERTENSIONAHA.111.00575 
196. Wang A, Rana S, Karumanchi SA (2009) Preeclampsia: the role of angiogenic factors in its pathogenesis. Physiology 24:147158. https://doi.org/10.1152/physiol.00043.2008

197. August P, Lenz T, Ales KL et al (1990) Longitudinal study of the renin-angiotensin-aldosterone system in hypertensive pregnant women: deviations related to the development of superimposed preeclampsia. Am J Obstet Gynecol 163:1612-1621. https://doi. org/10.1016/0002-9378(90)90639-o

198. Lumbers ER, Delforce SJ, Arthurs AL, Pringle KG (2019) Causes and consequences of the dysregulated maternal reninangiotensin system in preeclampsia. Front Endocrinol 10:563. https://doi.org/10.3389/fendo.2019.00563

199. Campbell N, LaMarca B, Cunningham MW (2018) The role of agonistic autoantibodies to the Angiotensin II type 1 receptor (AT1-AA) in pathophysiology of preeclampsia. Curr Pharm Biotechnol 19:781-785. https://doi.org/10.2174/138920101966618 0925121254

200. Phipps E, Prasanna D, Brima W, Jim B (2016) Preeclampsia: updates in pathogenesis, definitions, and guidelines. Clin J Am Soc Nephrol 11:1102-1113. https://doi.org/10.2215/CJN.12081 115

201. Buttrup Larsen S, Wallukat G, Schimke I et al (2018) Functional autoantibodies against Endothelin-1 receptor type A and Angiotensin II receptor type 1 in patients with preeclampsia. Pregnancy Hypertens 14:189-194. https://doi.org/10.1016/j.preghy.2018.10. 002

202. Hofmann H, Geier M, Marzi A et al (2004) Susceptibility to SARS coronavirus $\mathrm{S}$ protein-driven infection correlates with expression of angiotensin converting enzyme 2 and infection can be blocked by soluble receptor. Biochem Biophys Res Commun 319:1216-1221. https://doi.org/10.1016/j.bbrc.2004.05.114

203. Li M, Chen L, Zhang J et al (2020) The SARS-CoV-2 receptor ACE2 expression of maternal-fetal interface and fetal organs by single-cell transcriptome study. PLoS ONE 15:e0230295. https:// doi.org/10.1371/journal.pone.0230295

204. Liu PP, Blet A, Smyth D, Li H (2020) The science underlying COVID-19: implications for the cardiovascular system. Circulation. https://doi.org/10.1161/CIRCULATIONAHA.120.047549

205. Cheng Y, Luo R, Wang K et al (2020) Kidney disease is associated with in-hospital death of patients with COVID-19. Kidney Int 97:829-838. https://doi.org/10.1016/j.kint.2020.03.005

206. Kreutz R, Algharably EAE-H, Azizi M et al (2020) Hypertension, the renin-angiotensin system, and the risk of lower respiratory tract infections and lung injury: implications for COVID-19. Cardiovasc Res. https://doi.org/10.1093/cvr/cvaa097

207. Gheblawi M, Wang K, Viveiros A et al (2020) Angiotensinconverting enzyme 2: SARS-CoV-2 receptor and regulator of the renin-angiotensin system: celebrating the 20th Anniversary of the Discovery of ACE2. Circ Res 126:1456-1474. https://doi. org/10.1161/CIRCRESAHA.120.317015

208. Yu N, Li W, Kang Q et al (2020) No SARS-CoV-2 detected in amniotic fluid in mid-pregnancy. Lancet Infect Dis. https://doi. org/10.1016/S1473-3099(20)30320-0

209. Zhu H, Wang L, Fang $C$ et al (2020) Clinical analysis of 10 neonates born to mothers with 2019-nCoV pneumonia. Transl Pediatr 9:51-60. https://doi.org/10.21037/tp.2020.02.06

210. Chen P, Zhou B (2020) Clinical characteristics of COVID-19 patients with abnormal liver tests. J Hepatol. https://doi.org/10. 1016/j.jhep.2020.04.028

211. Lippi G, Plebani M, Henry BM (2020) Thrombocytopenia is associated with severe coronavirus disease 2019 (COVID-19) infections: a meta-analysis. Clin Chim Acta 506:145-148. https://doi.org/10.1016/j.cca.2020.03.022
212. ACOG Committee on Obstetric Practice (2002) ACOG practice bulletin. Diagnosis and management of preeclampsia and eclampsia. Number 33, January 2002. American College of Obstetricians and Gynecologists. Int J Gynaecol Obstet 77:67-75

213. Brown MA, Magee LA, Kenny LC et al (2018) The hypertensive disorders of pregnancy: ISSHP classification, diagnosis \& management recommendations for international practice. Pregnancy Hypertens 13:291-310. https://doi.org/10.1016/j.preghy.2018.05. 004

214. Weber M, Hamm C (2006) Role of B-type natriuretic peptide (BNP) and NT-proBNP in clinical routine. Heart 92:843-849. https://doi.org/10.1136/hrt.2005.071233

215. Bhatraju PK, Ghassemieh BJ, Nichols M et al (2020) Covid-19 in critically Ill patients in the seattle region-case series. N Engl J Med. https://doi.org/10.1056/NEJMoa2004500

216. Gao L, Jiang D, Wen X et al (2020) Prognostic value of NTproBNP in patients with severe COVID-19. Respir Res. https:// doi.org/10.1186/s12931-020-01352-w

217. Dietl A, Stark K, Zimmermann ME et al (2016) NT-proBNP predicts cardiovascular death in the general population independent of left ventricular mass and function: insights from a large population-based study with long-term follow-up. PLoS ONE 11:e0164060. https://doi.org/10.1371/journal.pone.0164060

218. Yan W, Sheng N, Seto M et al (1999) Corin, a mosaic transmembrane serine protease encoded by a novel cDNA from human heart. J Biol Chem 274:14926-14935. https://doi.org/10.1074/ jbc.274.21.14926

219. Tihtonen KM, Kööbi T, Vuolteenaho O et al (2007) Natriuretic peptides and hemodynamics in preeclampsia. Am J Obstet Gynecol 196:328.e1-7. https://doi.org/10.1016/j.ajog.2006.11. 033

220. Kumari M, Kovach T, Sheehy B et al (2019) Circulating NTproBNP but not soluble corin levels were associated with preeclampsia in pregnancy-associated hypertension. Clin Biochem 67:12-15. https://doi.org/10.1016/j.clinbiochem.2019.03.005

221. Resnik JL, Hong C, Resnik R et al (2005) Evaluation of B-type natriuretic peptide (BNP) levels in normal and preeclamptic women. Am J Obstet Gynecol 193:450-454. https://doi.org/10. 1016/j.ajog.2004.12.006

222. Junus K, Wikstrom A-K, Larsson A, Olovsson M (2014) Placental expression of proBNP/NT-proBNP and plasma levels of NTproBNP in early- and late-onset preeclampsia. Am J Hypertens 27:1225-1230. https://doi.org/10.1093/ajh/hpu033

223. Bellamy L, Casas J-P, Hingorani AD, Williams DJ (2007) Preeclampsia and risk of cardiovascular disease and cancer in later life: systematic review and meta-analysis. BMJ 335:974. https:// doi.org/10.1136/bmj.39335.385301.BE

224. Irgens HU, Reisaeter L, Irgens LM, Lie RT (2001) Long term mortality of mothers and fathers after pre-eclampsia: population based cohort study. BMJ 323:1213-1217. https://doi.org/ 10.1136/bmj.323.7323.1213

225. Verlohren S, Perschel FH, Thilaganathan B et al (2017) Angiogenic markers and cardiovascular indices in the prediction of hypertensive disorders of pregnancy. Hypertension 69:11921197. https://doi.org/10.1161/HYPERTENSIONAHA.117.09256

Publisher's Note Springer Nature remains neutral with regard to jurisdictional claims in published maps and institutional affiliations. 